\title{
Early Jurassic arc related magmatism associated with porphyry copper mineralization at Zafranal, Southern Peru unraveled by zircon $\mathrm{U}-\mathrm{Pb}$ ages
}

\author{
*Alan Santos ${ }^{1,4}$, Guo Weimin ${ }^{2}$, Fernando Rivera $^{3}$, Colombo Tassinari ${ }^{4}$, Luis Cerpa ${ }^{5}$, Shoji Kojima ${ }^{1}$
}

\author{
${ }^{1}$ Universidad Católica del Norte, Av. Angamos 0610, Antofagasta, Chile. \\ alanpolo30@gmail.com; skojima@ucn.cl \\ ${ }^{2}$ Nanjing Center, China Geological Survey, 534 Este Calle Zhongshan, China. \\ mwguo@163.com \\ ${ }^{3}$ Universidad Nacional Mayor de San Marcos, Lima distrito 15081, Perú. \\ ing.fernandorivera@hotmail.com \\ ${ }^{4}$ Instituto de Geociencias de la Universidad de Sao Paulo, Rua do Lago, 526, Sao Paulo Brasil. \\ ccgtassi@usp.br \\ ${ }^{5}$ Instituto Geológico Minero y Metalúrgico, Av. Canadá 1470-San Borja, Lima, Perú. \\ lcerpa@ingemmet.gob.pe
}

*Corresponding author: alanpolo30@gmail.com

\begin{abstract}
Early Jurassic arc-related igneous rocks host porphyry copper prospects and gold-bearing quartz vein deposits in southern Peru. Ten new zircon U-Pb ages for wall rocks of gold-bearing quartz veins, Jurassic rocks and copper-mineralized porphyry bodies in Zafranal porphyry copper, together with published ages for Jurassic rocks, reveal a continuous magmatic evolution of the early Jurassic arc. The Jurassic rocks and gold-bearing quartz vein systems in the western flank of the Western Cordillera are hosted by Paleo- and Meso-proterozoic orthogneisses of the Arequipa Massif $(1.75-1.44 \mathrm{Ga})$ that underwent Grenville-age metamorphism $\sim 1 \mathrm{Ga}$. The early mafic magmatism is recorded between 199.6-193.2 Ma, and was followed by dominantly felsic magmatism from 184.1-174.9 Ma. Both magmatic events have formed the thinnest intrusive belt $(<15 \mathrm{~km}$ wide) of the Coastal Batholith in southern Peru. The last magmatic event of the early Jurassic (181.0-174.9 Ma) is represented by several phases of porphyries associated with copper mineralization in the Zafranal porphyry copper deposit. The published ages indicate that the magmatic arc migrated along eastern limit of the Arequipa Massif during Middle Jurassic. In the late Jurassic ( 146 Ma) the magmatic locus returned near early Jurassic intrusion. Overall, the plutonic intrusive rocks and porphyry bodies with copper mineralization represent the oldest magmatic events of the Coastal Batholith of Peru formed during the early Jurassic.
\end{abstract}

Keywords: Coastal Batholith, Zafranal porphyry, Early Jurassic, U-Pb zircon age, SHRIMP.

RESUMEN. Magmatismo relacionado al arco Jurásico temprano asociado con la mineralización pórfido de cobre en Zafranal, Sur de Perú, esclarecido mediante edades U-Pb en circones. Las rocas ígneas relacionadas al arco Jurásico temprano del sur de Perú albergan prospectos de pórfidos cupríferos y depósitos de vetas de cuarzo con contenido de oro. Diez nuevas edades U-Pb en circones de la roca caja de las vetas de cuarzo con oro, rocas jurásicas y stocks porfiríticos con mineralización cuprífera del pórfido de cobre Zafranal, junto con edades publicadas para las rocas jurásicas, revelan una continua evolución magmática del arco Jurásico temprano. Las rocas jurásicas y los sistemas de vetas de cuarzo con contenido de oro en el flanco oeste de la Cordillera Occidental están alojadas en ortogneis del Paleo y Meso-Proterozoico del Macizo de Arequipa (1.75-1.44 Ga) que sufrieron metamorfismo de edad Grenvilliana $\sim 1 \mathrm{Ga}$. El magmatismo máfico se registra entre 199.6-193.2 Ma, y fue seguido por magmatismo predominantemente félsico desde 184,1-174,9 Ma. Ambos eventos magmáticos han formado el cinturón intrusivo más delgado $(<15$ km de ancho) del Batolito de la Costa del sur de Perú. El último evento magmático del Jurásico temprano está representado 
por varias fases de stocks porfiríticos asociados con la mineralización cuprífera en el pórfido de cobre Zafranal, con emplazamientos durante los 181.0-174.9 Ma. Edades publicadas indican que el arco magmático migró a lo largo del límite este del afloramiento principal del Macizo de Arequipa durante el período Jurásico medio. En el Jurásico tardío ( $\sim 146 \mathrm{Ma})$ el foco magmático retornó cerca de las intrusiones del Jurásico temprano. En general, las rocas intrusivas y los stocks porfiríticos asociados con mineralización de cobre representan los eventos magmáticos más antiguos del Batolito de la Costa del Perú que se formaron durante el Jurásico temprano.

Palabras clave: Batolito de la Costa, Pórfido Zafranal, Jurásico temprano, Edades U-Pb en circones, SHRIMP.

\section{Introduction}

Considerable volumes of magma in the Peruvian convergent margin magmatic-arc, that formed the Coastal Batholith, were generated during a protracted time span (Jenks and Harris, 1953; Cobbing and Pitcher, 1972; Cobbing et al., 1977). Mesozoic plutons were emplaced within metamorphic rocks of Arequipa Massif (Stewart et al., 1974; Cobbing et al., 1977; Casquet et al., 2010). In the Arequipa Segment the emplacement zone $(<15 \mathrm{~km}$ wide) was controlled by large faults (Caldas, 1993; Demouy et al., 2012). These faults integrated in the Cincha-Lluta fault system, are thought to have generated crustal weakness zones that allowed repetitive injections of magma (Caldas, 1993) and associated copper-gold mineralization (Carlotto et al., 2009a). The mineralization includes gold-bearing quartz veins and porphyry type deposits, and thus a significant number of porphyry copper and associated Mesozoic magmatic-hydrothermal deposits prospects have been identified (Fig. 1). The porphyry copper prospects show a marked tendency to occur in typically orogen-parallel linear belts (Sillitoe and Perelló, 2005) or within magmatic arc (Seedorff et al., 2005). Each belt corresponds to a magmatic arc of broadly similar overall dimensions (Sillitoe, 2010); furthermore, each metallogenic belt migrates systematically farther east, related to the magmatic arc (Sillitoe, 2003). Determining the temporal and spatial evolution of the magmatic arcs of Coastal Batholith (Arequipa Segment; Cobbing et al., 1977), in southern Peru will contribute to our understanding of metallogenic epoch, as a first order approach for exploration targets. According to the geochronological data the Coastal Batholith was considered to have been emplaced in late Cretaceous (Cobbing and Pitcher, 1972; Stewart et al., 1974; Cobbing et al., 1977; Weibel et al., 1978; Cordani et al., 1985; Beckinsale et al., 1985; Mukasa, 1986; Caldas, 1993; Schildgen et al., 2009; Carlotto et al., 2009a), but afterwards divided into two groups one early Jurassic and other Upper Cretaceous
(Demouy et al., 2012; Boeckhout, 2012). However, the emplacement of the first magmatic suites of the Coastal Batholith, occur during the early Jurassic and is located from Arequipa to Chuquibamba (Fig. 1). Early Jurassic rocks are registered in southern Arequipa by Mukasa (1986), who considered that the extent of this arc remains unsolved. Thus, more recent studies (Demouy et al., 2012; Boeckhout, 2012) have focused on the Jurassic arc extent close to Arequipa. Therefore, this study aims to determine the early Jurassic arc extent to the northwest of Arequipa and crystallization age of porphyry bodies related to copper mineralization in Zafranal porphyry copper deposit by means of zircon $\mathrm{U}-\mathrm{Pb}$ ages with sensitive high-resolution ion microprobe (SHRIMP) and laser ablation inductively-coupled plasma spectrometry (LA-ICP-MS) determinations. Furthermore, this paper describes the regional geological setting of Jurassic intrusive rocks (Coastal Batholith-Arequipa Segment), with particular emphasis on the porphyritic bodies that host the copper mineralization in Zafranal, based on more than four years of fieldwork by the authors during a study of the Coastal Batholith program that included 1:25,000-scale regional mapping.

\section{Tectonomagmatic setting}

The early Jurassic intrusive rocks of southern Peru extends for $\sim 130 \mathrm{~km}$ between latitudes $15^{\circ} 48^{\prime}$ and $16^{\circ} 36^{\prime} \mathrm{S}$ and contains copper and gold-bearing mineral deposits, such as porphyry copper and gold-bearing quartz veins (Fig. 1). The oldest rocks within the study area are assigned to the metamorphic Arequipa Massif (Cobbing and Pitcher, 1972) of Proterozoic age (Cobbing et al., 1977; Dalmayrac et al., 1977; Shackleton et al., 1979). This massif represents the site of a complex history of sedimentation, magmatism and metamorphism in the Paleoproterozoic, and development of a sedimentary basin in the Mesoproterozoic (Casquet et al., 2010). The Arequipa Massif was accreted to the western margin 

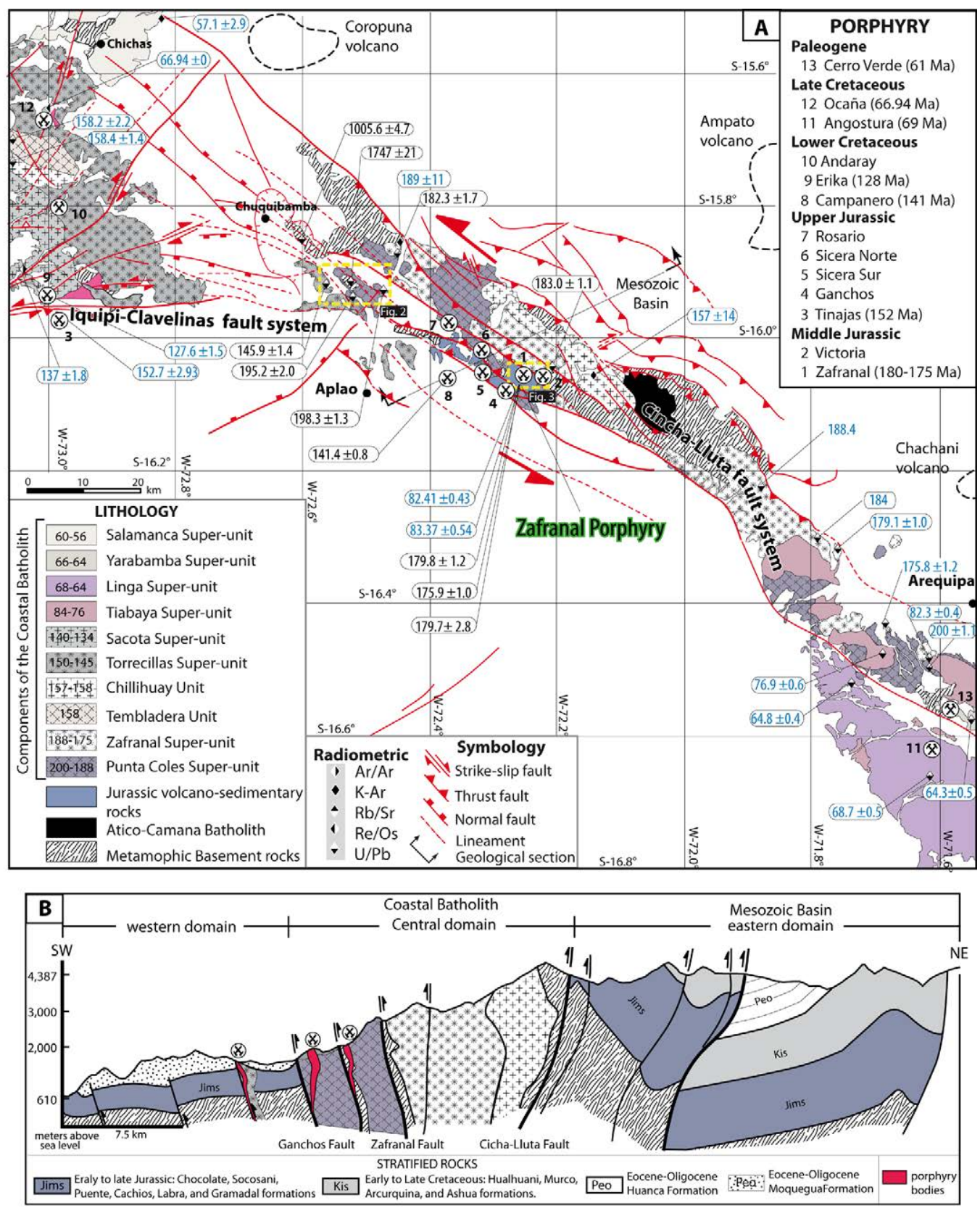

FIG. 1. A. Regional geologic map of the northern sector of the Arequipa Segment with the location of the main porphyry copper deposit (modified from Santos et al., 2016). The age data of blue letters are compiled from Stewart et al. (1974); Cordani et al. (1985); JICA (1986); Mukasa (1986); Demouy et al. (2012); Rivera (2012a); Huaman et al. (2014); Santos et al. (2016), and those of black letters are obtained in this work. B. Geological section. The location is in map.

of Gondwana, in the late Proterozoic related to the Sunsas orogeny (Wasteneys et al., 1995; Loewy et al., 2004; Chew et al., 2007; Ramos, 2008). Following, terrane accretion, between 850 to $650 \mathrm{Ma}$ the Andean margin of Peru was quiescent (James, 1971; Chew et al., 2008; Acosta and Sempere, 2017). During in the Early Paleozoic (Ordovician and Silurian-Devonian) it was affected by extensive 
tectonic events and development of coast-parallel magmatic arcs (Shackleton et al., 1979; Mukasa and Henry, 1990; Bahlburg et al., 2006; Reitsma, 2012). Subsequently, Permian-Triassic rifting along the western margin of Gondwana marks the beginning of the Andean orogenesis (Davidson and Mpodozis 1991; Benavides, 1999).

Since $c a$. Mid-Mesozoic (200-90 Ma), the Andean evolution seems to be more directly controlled by plate convergence (Coira et al., 1982; Thorpe, 1984; Allmendinger et al., 1997; Ramos and Aleman, 2000). It was dominated by periods of intracontinental rifting (Petford and Atherton, 2003) and formation of a well-defined intra-arc and back-arc basins (Coira et al., 1982; Atherton et al., 1983; Davidson and Mpodozis, 1991). Mesozoic intra-arc and back-arc rifts were filled vertically up through axial faults by magmas derived from the upper mantle or lower crust (Couch et al., 1981; Atherton et al., 1983, 1985), as well as sedimentary detritus derived from the rift margins, volcanic edifices (Benavides, 1956) and locally interbedded calcareous sedimentary rocks (Benavides, 1962). Marine sedimentation continue more or less uninterruptedly from the Jurassic into the early Cretaceous (Benavides, 1956). The rifting along the western margin of Peru were controlled by regionalscale axial fault systems, which correspond to the NW-striking Cincha-Lluta Fault System (CLFS) (Carlotto et al., 2009a; Simmons et al., 2013), which was active during batholith construction (Demouy et al., 2012). This fault system is equivalent to the Icapuquio Fault System (IFS) farther south in Peru (Wilson and García, 1962; Vargas, 1970; Vicente et al., 1979; Jacay et al., 2002), which controls the spatial distribution of most of the porphyry $\mathrm{Cu}-\mathrm{Mo}$ deposits, including the Zafranal porphyry district (Fig. 1). Furthermore, Zafranal porphyry copper is located very close to the intersection with the IquipiClavelinas Fault System (ICFS) of EW orientation.

The late Cretaceous-Paleocene (90-52 Ma), Peruvian continental margin was dominated by compressional tectonics (Isacks, 1988, and references therein; Camus, 2003). This marks the beginning of crustal thickening (Vicente, 1989; Jaillard, 1992; Carlotto et al., 2009b), produced by structural shortening of the crust and uplift due to thermal thinning of the lithosphere by delamination (James, 1971; Isacks, 1988; Sobolev and Babeyko, 2005; Oncken et al., 2006; Wipf, 2006). The old fault systems (CLFS and IFS) changed from normal to reverse thrust regime, and as a result the magmatic arc installed within the Arequipa Massif begins to uplift and separates the Arequipa Basin from the ocean (Carlotto et al., 2009a), starting the accumulation of the entirely subaerial volcanic rocks linked to Toquepala Group (Clark et al., 1990a). Plutonic bodies of the Yarabamba Super-unit (Coastal Batholith) intruded the Toquepala Group (Stewart et al., 1974; Mukasa, 1986; Beckinsale et al., 1985; Boily et al., 1989; Clark et al., 1990a; Martínez and Cervantes, 2003), and obscured much of the earlier rift sequence and late Cretaceous fold-and-thrust belt. Porphyry copper deposits are associated with Paleocene and Early Eocene granite and granodiorite porphyry stocks (Simmons et al., 2013).

Eocene-Oligocene (52-30 Ma), the tectonomagmatic events were controlled by the evolution of a flat-slab subduction regime (Sandeman et al., 1995; Noury et al., 2017), which caused a farther northeast migration of the locus of magmatism (Andahuaylas-Yauri Batholith; Sandeman et al., 1995; Perelló et al., 2003). Furthermore, uplift in the Precordillera, the Arequipa Massif is overturned and thrusted over the Mesozoic rocks (Vicente, 1989; Caldas, 1993), followed by erosion-degradation of the older magmatic arc and Jurassic basin allowed the development of the syn-orogenic Querque foreland and Moquegua forearc basins (Vicente, 1989; Jaillard, 1992; Carlotto et al., 2009b).

Early Miocene (24-17 Ma), extensive explosive volcanism of the Huaylillas Formation mantled the degradational Altos de Camilaca surface recorded in the Moquegua Formation (Tosdal et al., 1981, 1984; Quang et al., 2003, 2005). A late Miocene to Holocene, phase of Andean uplift (Isack, 1988; Roperch et al., 2006), was accompanied by widespread ignimbrite eruptions of the Chuntacala Formation (14-8 Ma), and andesitic volcanism of the Pliocene-Holocene Barroso Group ( $<5 \mathrm{Ma}$ ) and exhumation of the giant porphyry copper deposits (Tosdal et al., 1981, 1984; Clark et al., 1990b; Quang et al., 2005), based on the size classification proposed by Clark (1993).

\subsection{Tectonics and stratigraphy}

Arequipa Segment of the Coastal Batholith comprises three main tectonic domains bounded by high-angle NW-striking faults (Fig. 1). The eastern domain, east of the Cincha-Lluta Fault System (CLFS), contains basement blocks, composed of migmatite 
and gneiss (Wasteneys et al., 1995). These basement blocks, were intruded by diorites, sienogranitesmonzogranites of Ordovician age $(466.1 \pm 2.6 \mathrm{Ma}$; Santos et al., 2016). Both the basement and intrusive rocks are overlain by volcanic breccias and andesitic flows of Chocolate Formation, and limestones of Socosani Formation (Romero and Ticona, 2003). Towards the Mesozoic Basin (Fig. 1B), the sedimentary outcrops are approximately $>5 \mathrm{~km}$ thick (Romero and Ticona, 2003), divided into Chocolate, Socosani, Puente, Cachios, Labra, Gramadal, Hualhuani, Murco, Arcurquina, and Ashua Formations, which are strongly deformed showing sub-isoclinal folds, vertical and overturned strata. These strata are unconformably overlain by $>2 \mathrm{~km}$-thick of conglomerates, sandstones, and some volcanic breccias of the Huanca Formation (Querque Basin). The main Cincha-Lluta fault is characterized by high-angle NE-emergent, NW-striking, reverse fault and with a sinistral component.

The central domain (Fig. 1B), is located farther west of the Western Cordillera, and here, the basement rocks (Arequipa Massif) are intruded by plutonic complexes of the Coastal Batholith. These rocks together have an elongate geometry with orientation $\mathrm{N} 145^{\circ}$, parallel to the main faults and orogen of NW-orientation. Furthermore, in areas where intrusive rocks were cut by sinistral faults, many mylonites and shear zones occur in some place. There are roof pendants of basement rocks (e.g., Cerro Gandolfo; Fig. 2), as well as volcano-sedimentary sequences of the Chocolate Formation (e.g., Zafranal porphyry). Plutonic rocks, ranging in composition from diorites and granites through quartz diorites to tonalites-granodiorites, were emplaced throughout the Arequipa Massif of relatively variable large to short pulses, each estimated to last roughly 4 to $12 \mathrm{Ma}$ (Pitcher, 1985; Santos et al., 2016).

In the western domain, the Mesozoic rocks are covered by sedimentary rocks of the Moquegua Formation (Fig. 1B). This unit comprises mainly conglomerates, sandstones, siltstones with evaporite intercalations and tuffs with ages K-Ar of 25.3 to $22.8 \mathrm{Ma}$ (Tosdal et al., 1981; Quang, 2005). A number of high-angle reverse faults of the Western Andean Escarpment cut both Mesozoic sedimentary bedrock and lower Moquegua red beds. Near the town of Aplao, a reverse fault dipping approximately $70^{\circ} \mathrm{NE}$ places Chocolate Formation over lower Moquegua, but deformation decreases up section, with upper Moquegua group strata deformed into a monocline and erosionally stripped (Schildgen et al., 2009). In the early Miocene (23-17 Ma), ignimbrite flows of the Huaylillas Formation were deposited on the surface of erosion of the Moquegua Formation (Tosdal et al., 1981; Quang et al., 2005).

\section{Regional geology of ore deposits}

The studied area is a thin strip $(<15 \mathrm{~km}$ wide) of rocks belonging to the Coastal Batholith. This area contains gold-bearing quartz veins hosted in metamorphic and volcano-sedimentary rocks, and porphyry copper deposits (Fig. 1).

\subsection{Intrusion-related gold-bearing quartz vein systems}

Vein-type deposits are by far the most abundant and common mineralization style in the Coastal Cordillera (Sillitoe, 2003). The Rinconada de Chapi and Copacabana mining districts are located in the Quebrada Ongoro, $18 \mathrm{~km}$ southeast of the town of Chuquibamba (Figs. 1A and 2), and include goldbearing quartz vein mineralization (e.g., Palpa-Ocoña, southern Peru; Sillitoe and Thompson, 1998). These quartz veins occur as NW-SE strycking swarms and with NEE-SWW orientations related to the main fault systems (CLFS and ICFS). In Copacabana, the gold-bearing quartz veins have the orthogneiss of the Arequipa Massif as wall rocks. These orthogneiss show a granoblastic texture, whit quartz, K-feldspar and plagioclase with biotite in thin bands and lenticular structures. The mineralization occurs as tabular quartz veins (dips $>60^{\circ} \mathrm{S}$ ), with a marked structural control in a $\mathrm{N} 70^{\circ} \mathrm{E}$ trend. The major veins are 0.3 to $0.5 \mathrm{~m}$ thick. They consist mainly of quartz containing pyrite, chalcopyrite and native gold, and as supergene mineral contain hematite, goethite and copper-oxides (mainly chrysocolla). The higher grades range from 10 to $12 \mathrm{~g} / \mathrm{t} \mathrm{Au}$. Hydrothermal alteration of the host rocks is common in many areas around the quartz veins, and consists of kaolinization and subordinate chloritization. At Rinconada de Chapi the veins are hosted in a volcano-sedimentary sequence and dikes complex intensely deformed, as indicated by vertical and overturned strata, anastomosing and thrust-bounded tectonic lenses of the Chocolate Formation. The ore deposits occur as steep-dipping tabular quartz veins (dips $>80^{\circ} \mathrm{N}$ ), with marked structural control and discontinuous longitudinal development in a NW-SE 


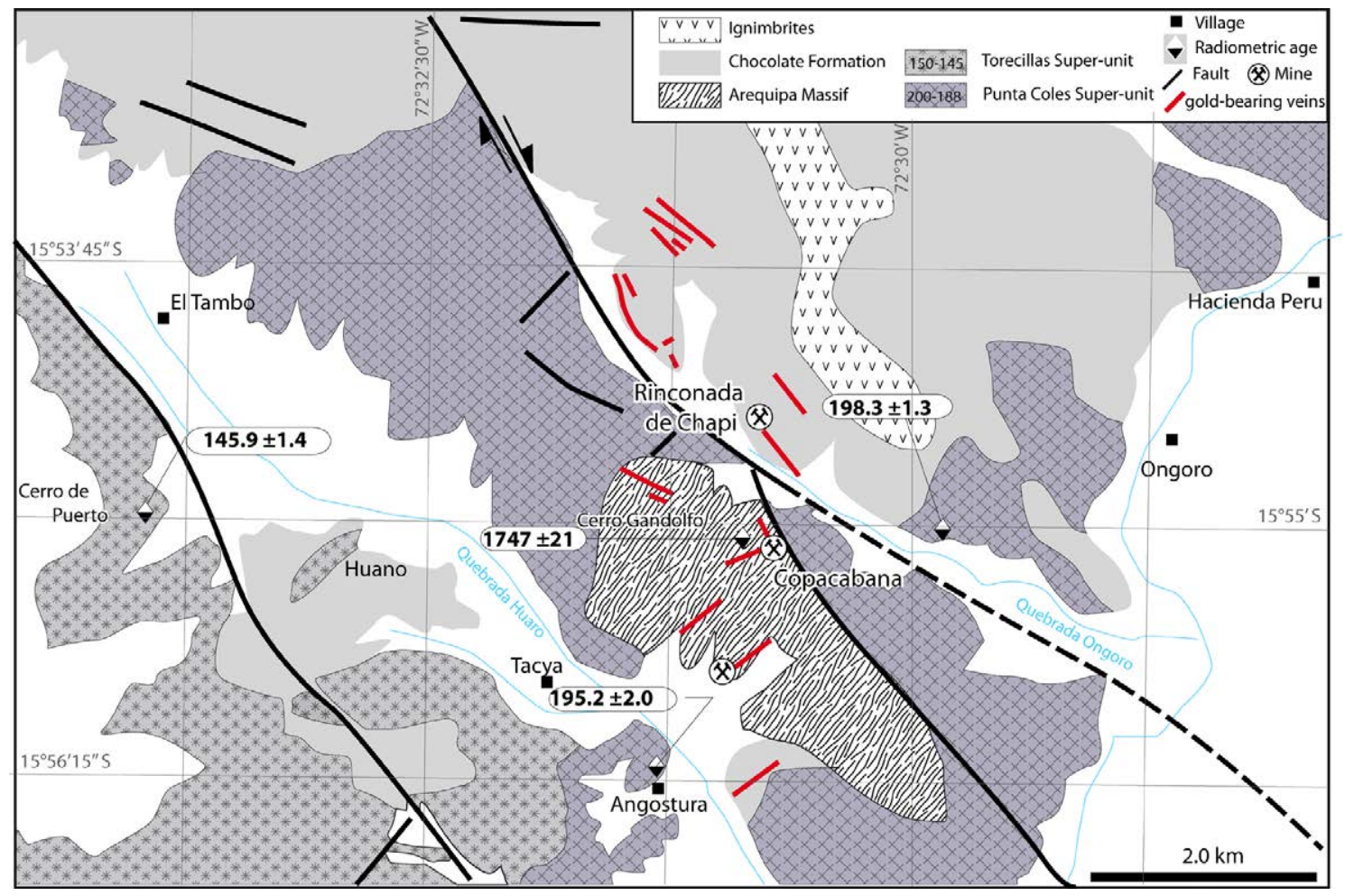

FIG. 2. Arequipa Massif and Chocolate Formation rocks-hosted gold-bearing quartz veins and controlling faults in the Quebrada Ongoro (Modified from INGEMMET, 2001). Radiometric age obtained in this work. Map location is in figure 1.

direction $\left(\mathrm{N} 140^{\circ}\right)$ reaching $1 \mathrm{~km}$ along strike. The major quartz veins are $<0.8 \mathrm{~m}$ thick. They consist mainly of quartz, pyrite, chalcopyrite and native gold, and as secondary mineral contains calcite, hematite, chrysocolla and malachite. The higher grades range from 10 to $15 \mathrm{~g} / \mathrm{t} \mathrm{Au}$. Also there are some thin veins $(<10 \mathrm{~cm})$, with quartz and galena.

Rocks of the Arequipa Massif and Chocolate Formation were intruded by diorites to quartz diorite of the Punta Coles Super-unit, cropping out largely in the Quebrada Ongoro, but also to the northeast part of gold-bearing quartz vein district. Based on the fact that the diorite-quartz diorite intrusive truncates the gold-bearing quartz veins hosted in rocks of the Arequipa Massif, it is inferred that the formation of these mineral deposits occurred before the emplacement of the dioritic-quartz dioritic intrusive (Cerro Gandolfo, Fig. 2). The bulk of the Punta Coles super-unit is made up of light- to medium-dark gray to greenish, hypidiomorphic granular diorite in the central part (following IUGS classification, Streckeisen, 1973), towards the boundaries increases the quartz content and reduces its grain size (Quebrada Ongoro). In general, these rocks are composed of a dominance of plagioclase over chloritized amphibole and traces of biotite. Minor quartz and sericitized K-feldspar occur interstitially in the equigranular phase.

\subsection{Zafranal porphyry copper}

The Zafranal porphyry copper deposit is located approximately $90 \mathrm{~km}$ northwest of the city of Arequipa in southern Peru, it was first described by Tejada (2010). Measured and indicated resources amount $>472.1 \mathrm{Mt}, 0.36 \% \mathrm{Cu}$ and @ $0.08 \mathrm{~g} / \mathrm{t} \mathrm{Au}$ (Fernandez-Baca, 2011). The Zafranal local geology was described by geologists of AQM Peru S.A.C. (De Ruijter et al., 2013) and summarized by Rivera et al. (2010), Rivera (2012a, b). Metamorphic rocks of the Arequipa Massif are the oldest rocks at Zafranal, cropping out largely along the shear zone of the NW-striking Zafranal reverse fault. The next younger units are volcano-sedimentary sequences of the Chocolate Formation comprised of sandstone and 
siltstones, which in turn are overlain by tuffs, breccias and andesitic lava flows (Rivera et al., 2010; Fig. 3), which are present as roof pendants in igneous intrusions. Several roof pendants and large blocks of volcano-sedimentary sequences are present in the pre-mineralization diorites-granodiorites, which form the northern margin of the Zafranal porphyry. Alteration and mineralization at Zafranal is centered on porphyritic dykes and stock complexes, ranging in composition from diorite to quartz diorite, which show potassic alteration dominated by biotite (Tejada, 2010). The older porphyry suite (Zafranal diorite) host copper mineralization, displaying intense sericitic alteration overprinted on potassic alteration (Rivera et al., 2010), including typical A-type chalcopyrite-pyrite and B-type chalcopyrite-molybdenite quartz veinlets, and D-type quartz-pyrite-chalcopyrite veinlets with sericitic halos (cf. Gustafson and Hunt, 1975). An outer propylitic halo with epidote-chlorite, approximately $400 \mathrm{~m}$ wide, is present to the north (Rivera, 2012a). A ${ }^{40} \mathrm{Ar} /{ }^{39} \mathrm{Ar}$ plateau age of $82.41 \pm 0.43 \mathrm{Ma}$ was obtained for hydrothermal biotite of the Zafranal diorite (Rivera, 2012a), located close to the east of the Zafranal porphyry system (Fig. 3). A microdiorite porphyry cut the Zafranal diorite, and is characterized by a much weaker potassic alteration towards depth, sparse A-, and B-type veinlets, containing 0.35-0.40 percent $\mathrm{Cu}$ in the hypogene mineralization (Rivera et al., 2010). $\mathrm{A}^{40} \mathrm{Ar} /{ }^{39} \mathrm{Ar}$ plateau ages of $83.370 \pm 0.54$ and $81.16 \pm 0.43 \mathrm{Ma}$ were obtained for hydrothermal biotites (Rivera, 2012a), in a microdiorite located in the central part of the Zafranal porphyry system (Fig. 3). Post-mineral intrusions diorite and dioritemonzodiorite dykes, displaying only weakly propylitic alteration with pyrite and chalcopyrite dissemination (Rivera, 2012a). However, U-Pb data presented herein demonstrates that the porphyries are temporally related to an early Jurassic magmatism.

Hydrothermal alteration and mineralization. Zafranal porphyry partly conform to the classic Lowell and Guilbert (1970) hydrothermal alteration zonation model, in which a potassic altered core grade laterally to an annular sericitic zone surrounded by a fringe of propylitic alteration (Rivera et al., 2010). The potassic alteration is defined by the presence of hydrothermal biotite, quartz and K-feldspar together with anhydrite, chalcopyrite \pm pyrite, and molybdenite, which make up the hypogene mineralization (Rivera, 2012a). Hornblende and magmatic biotite in the igneous rocks are almost totally replaced by finegrained, brown biotite, and plagioclase is partially replaced by K-feldspar. The sericitic alteration clearly overprinted and destroys the earlier formed potassic assemblage and comprises quartz, sericite, and pyrite.

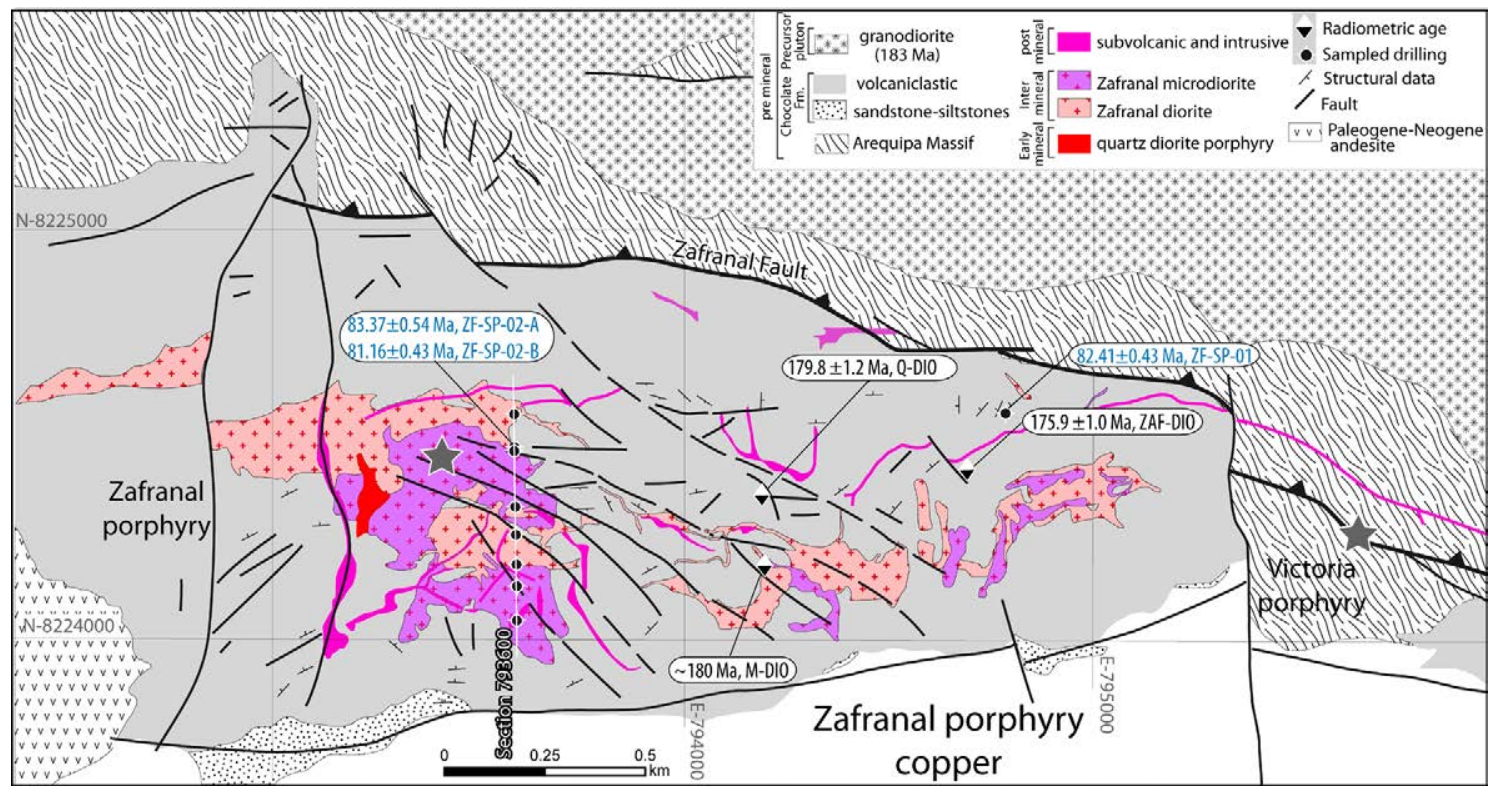

FIG. 3. Geologic map of Zafranal porphyry copper (De Ruijter et al., 2013). The age data in blue letters are compiled from Rivera (2012a) and those in black letters are obtained in this work. Map location is in figure 1. 
Chalcopyrite is partially replaced by supergene chalcocite and covelite (Tejada, 2010). Intermediate argillic alteration is characterized by the presence of illite, chlorite and sericite together with kaolinite and smectite. Locally, internal parts of the southern limit of the deposit contain quartz, alunite, kaolinite and illite, minerals denoting the existence of advanced argillic alteration.

Supergene alteration and mineralization. The upper oxidized zone averages $\sim 60 \mathrm{~m}$ thick, which is located within the leached capping (30-200 m thick), associated with the zone of sericitic alteration (Rivera et al., 2010). In the oxidized zone, chrysocolla, malachite, chalcanthite and neotocite are the ore minerals. The supergene enriched blanket average $\sim 75 \mathrm{~m}$ thick, but locally attains a maximum of $150 \mathrm{~m}$ (Rivera et al., 2010), where the chalcocite and covellite occur as replacement coating on chalcopyrite, and minor pyrite grains. This supergene profile contains copper grades from 0.8 to $1 \%$ (Tejada, 2010).

\subsection{Late intrusions}

At Cerro de Puerto (Huano village, Fig. 2), a NW elongated pluton composed of hypidiomorphic, granular, amphibole-rich tonalite (Torrecillas Superunit, Fig. 1), extends from Chuquibamba up to northern Aplao. This pluton is cropping out close to Campanero porphyry copper prospect. The Campanero porphyry prospect (Rivera et al., 2008) is located approximately $14 \mathrm{~km}$ west of the Zafranal porphyry (Fig. 1).

Quartzite and siltstone of the Labra Formation are the oldest rocks at Campanero prospect, cropping out largely in the Rio Majes, but also in the central part of the prospect. Pre-mineralization granodiorite-tonalite are widely distributed to the northwest of the prospect. Copper mineralization is spatially and temporally related to a hornblende-rich quartz diorite with porphyritic texture. It presents high content of plagioclase, biotitized amphibole, and quartz. In general, the outcrops present strong sericitic alteration with hematite dissemination in matrix and veinlets. $\mathrm{A}{ }^{40} \mathrm{Ar} /{ }^{39} \mathrm{Ar}$ plateau age of $141.4 \pm 0.8 \mathrm{Ma}$ was obtained in hydrothermal biotite (Rivera, written communication, 2016).

\section{Sampling at Zafranal Porphyry copper deposit}

Sampling was conducted mainly in two transects (Fig. 1) and 10 representative samples of metamorphic and plutonic rocks as well as intrusives associated with porphyry copper mineralization in Zafranal deposit were selected for the U-Pb dating. Sample locations are shown in figure 1. Coordinates, unit, description, abbreviated mineralogy and the analytical work carried out on each sample are presented in table 1. Unit designations is following the nomenclature proposal of Cobbing et al. (1977) and Santos et al. (2016) (see Fig. 1).

\section{Analytical method}

New $\mathrm{U}-\mathrm{Pb}$ ages were obtained using a sensitive high-resolution ion microprobe (SHRIMP) at the Institute of Geosciences of the University of Sao Paulo-Brazil and laser ablation inductively coupled plasma spectrometry (LA-ICP-MS) at the Laboratory of China University of Geosciences (Wuhan).

Zircons grains were separated by standard procedures; including crushing, Wilfley table and a magnetic separation (Frantz), and gravimetric separation by dense liquids to obtain a zircon concentrate. Finally zircon grains were hand-picked under a binocular microscope. A representative set of zircons grains (including the different morphologies of each zircon population) were arranged in rows in a mounting tablet, and fixed with epoxy resin and were polished to standardize the external surfaces. Cathode-luminescence (CL) SEM images, were used to decipher the internal structures of the sectioned grains and to target specific areas within the zircons. The U-Pb isotope analysis were made, using a sensitive high-resolution ion microprobe (SHRIMP) in the same technique described by Sato et al. (2014) and laser ablation inductively coupled plasma spectrometry (LA-ICP-MS), the analytical method is reported in Liu (2011). Concordia ages and diagrams were generated using the Isoplot/Ex V.2.49 software package by Ludwig (2001). U-Pb data obtained are in Appendix (Table A1-A2) and results are described below as shown in figures 4-7.

\section{Zircon SHRIMP and LA_ICP-MS samples and results}

\subsection{Wall rock and gold-bearing quartz vein mineralization}

Wall rock. A granoblastic orthogneiss (sample 76, table 1) at Copacabana, taken from the wall rock of the quartz veins. The zircons from this sample 
TABLE 1. SHORT DESCRIPTION OF ROCKS SELECTED FOR U-Pb ZIRCON DATING.

\begin{tabular}{|c|c|c|c|c|c|c|c|}
\hline Sample & \multicolumn{2}{|c|}{ Coordinates } & Unit & $\begin{array}{l}\text { General } \\
\text { location }\end{array}$ & Rock type* & $\begin{array}{l}\text { Abbreviated } \\
\text { mineralogy** }\end{array}$ & $\begin{array}{l}\text { Analytical } \\
\text { work }\end{array}$ \\
\hline 76 & $72^{\circ} 31^{\prime} 15.899^{\prime} \mathrm{S}$ & $15^{\circ} 54 " 54.19^{\prime \prime} \mathrm{W}$ & $\mathrm{AM}$ & $\begin{array}{l}\text { Cerro } \\
\text { Gandolfo }\end{array}$ & otrhogeneiss & $\begin{array}{l}\text { Kfs, Qtz, Pl, Bt-Spn, Zrn-Ser, Ep, } \\
\text { Chl, Qtz }\end{array}$ & $\mathrm{L}$ \\
\hline 77 & $72^{\circ} 36^{\prime} 31.05^{\prime \prime} \mathrm{S}$ & $15^{\circ} 51^{\prime} 07.91 ’ \mathrm{~W}$ & $\mathrm{AM}$ & $\begin{array}{l}\text { Cerro } \\
\text { Francisco }\end{array}$ & otrhogeneiss & $\begin{array}{l}\text { Otz, Kfs, Bt, Am, Pl-Grt, Ap, Zrn- } \\
\text { Qtz, Chl, Ep }\end{array}$ & $\mathrm{L}$ \\
\hline 75 & $72^{\circ} 29^{\prime} 23.40^{\prime \prime} \mathrm{S}$ & $15^{\circ} 55^{\prime} 19.97 ’ \mathrm{~W}$ & $\mathrm{PC}$ & $\begin{array}{l}\text { Cerro } \\
\text { Ongoro }\end{array}$ & $\begin{array}{l}\text { quartz } \\
\text { diorite }\end{array}$ & Pl, Qtz-Am, Spn, Bt-Ep,Chl, Ser & $\mathrm{L}$ \\
\hline 82 & $72^{\circ} 31^{\prime} 17.46^{\prime \prime} \mathrm{S}$ & $15^{\circ} 56^{\prime} 11.80^{\prime \prime} \mathrm{W}$ & $\mathrm{PC}$ & $\begin{array}{l}\text { Village } \\
\text { Angostura }\end{array}$ & diorite & Pl, Am-Bt, Qtz, Spn, Fsp-Chl, Ser, Ep & $\mathrm{L}$ \\
\hline 89 & $72^{\circ} 27^{\prime} 09.88^{\prime \prime} \mathrm{S}$ & $15^{\circ} 52^{\prime} 07.40^{\prime \prime} \mathrm{W}$ & $\mathrm{Zaf}$ & $\begin{array}{l}\text { Village } \\
\text { Andamayo }\end{array}$ & tonalite & Pl, Qtz, Bt, Kfs-Am, Zrn-Chl-Ep & $\mathrm{L}$ \\
\hline $95 \mathrm{~A}$ & $72^{\circ} 12^{\prime} 16.811^{\prime} \mathrm{S}$ & $16^{\circ} 02^{\prime} 22.59^{\prime} \mathrm{W}$ & $\mathrm{Zaf}$ & $\begin{array}{l}\text { Victoria } \\
\text { prospect }\end{array}$ & granodiorite & Pl, Qtz, Kfs, Bt-Am, Zrn, Fsp-Chl-Ep & $\mathrm{L}$ \\
\hline Q-DIO & $72^{\circ} 15^{\prime} 09.66^{\prime \prime} \mathrm{S}$ & $16^{\circ} 02^{\prime} 46.58^{\prime \prime} \mathrm{W}$ & - & $\begin{array}{l}\text { aZafranal } \\
\text { porphyry }\end{array}$ & $\begin{array}{l}\text { quarzt } \\
\text { diorite }\end{array}$ & $\begin{array}{l}\text { Pl, Kfs, Qtz-Am, Bt, Zrn, Ap-Ser, } \\
\text { Chl, Qtz II, Spn, Ep }\end{array}$ & S \\
\hline ZAF-DIO & $72^{\circ} 14^{\prime} 53.55^{\prime \prime} \mathrm{S}$ & $16^{\circ} 02^{\prime} 44.32^{\prime \prime} \mathrm{W}$ & - & $\begin{array}{l}\text { bZafranal } \\
\text { porphyry }\end{array}$ & $\begin{array}{l}\text { quarzt } \\
\text { monzodiorite }\end{array}$ & $\begin{array}{l}\text { Pl, Qtz, Kfs-Ap, Zrn, Fsp, Am, } \\
\text { Bt-Chl, Ser, Qtz II, Spn, Ep, Bt II }\end{array}$ & $\mathrm{S}$ \\
\hline M-DIO & $72^{\circ} 15^{\prime} 09.69^{\prime \prime} \mathrm{S}$ & $16^{\circ} 02 ' 52.92 " \mathrm{~W}$ & - & $\begin{array}{l}\text { 'Zafranal } \\
\text { porphyry }\end{array}$ & microdiorite & Fsp, Qz-Am-Chl-Ser-Bt II & S \\
\hline 86 & $72^{\circ} 33^{\prime} 50.51^{\prime \prime} \mathrm{S}$ & $15^{\circ} 54^{\prime} 57.77^{\prime \prime} \mathrm{W}$ & Tor & $\begin{array}{l}\text { Cerro } \\
\text { Puerto }\end{array}$ & tonalite & Pl, Am, Qtz-Kfs, Spn, Bt-Ser, Ep, Chl & $\mathrm{L}$ \\
\hline
\end{tabular}

\begin{tabular}{|c|c|c|}
\hline Analytical work & : & $\mathbf{L}=\mathrm{U}-\mathrm{Pb}$ LA-ICP-MS; S = U-Pb SHRIMP. \\
\hline Unit & : & $\begin{array}{l}\text { AM }=\text { Arequipa Massif; } \mathbf{P C}=\text { Punta Coles Super-unit; } \mathbf{Z a f}=\text { Zafranal Super-unit; Tor }=\text { Torconta Super-unit, according } \\
\text { to Cobbing et al. }(1977) \text { and Santos } \text { et al. }(2016) .\end{array}$ \\
\hline General location & : & $\begin{array}{l}\text { samples from drill hole } \mathbf{a}=\text { ZFDDH10-024, depth } 230 \mathrm{~m} ; \mathbf{b}=\text { ZFDDH10-125, depth } 600 \mathrm{~m} \text {; c = ZFDDH11-166, depth } \\
650 \mathrm{~m} .\end{array}$ \\
\hline * & : & Following IUGS classification, Streckeisen (1973). \\
\hline$* *$ & & Mineral abbreviations according to Siivola and Schmid (2007) and Kretz (1983). \\
\hline
\end{tabular}

are equant elongate, to sub-round in shape and less than $200 \mu \mathrm{m}$ length. The CL images show large relict cores sub-round in shape, in some cases present igneous zoning, surrounded by mantles of variable thickness with homogeneous zoning rims, discordant to the earlier oscillatory zoning (Fig. 4A). Twenty spots were analyzed on 20 zircon grains, included cores and rims. Six of eleven cores plot near concordia and yield a mean U-Pb age of $1747 \pm 21 \mathrm{Ma}$ (MSWD=6.8), which is interpreted as the crystallization age of the igneous protolith. The very high $\mathrm{Th} / \mathrm{U}$ values of cores (1.69-1.05), typical of igneous zircons (Hoskin and Schaltegger, 2003), reinforce this interpretation. The remaining nine zircons were analyzed in the rims yielded $\mathrm{U}-\mathrm{Pb}$ ages between 1594-1076 Ma, the rims are high-U (mostly over 311-1240 ppm) and with low $\mathrm{Th} / \mathrm{U}$ ratios (mostly $<0.9$ ) indicative of an igneous origin with partially recrystallized rims. This decrease correlates with a decrease in the ${ }^{207} \mathrm{~Pb} /{ }^{206} \mathrm{~Pb}$ age of the zircon (Hoskin and Schaltegger, 2003).

The other sample of granoblastic orthogneiss (sample 77, table 1) from approximately $2 \mathrm{~km}$ southeast of the Chuquibamba (Fig. 1); The zircons from this sample are sub-round in shape and less than $170 \mu \mathrm{m}$ length. The CL images reveal small few relict cores, some cores preserve igneous zoning, and other cores show low-luminescence, in both cases the cores are girded by areas broad and homogeneous (Fig. 4B). Twenty spots were analyzed on 20 zircon 
grains. Three cores yielded $\mathrm{U}-\mathrm{Pb}$ ages between 1444-1383 Ma, containing zircon $\mathrm{Th} / \mathrm{U}$ ratios from $<0.7$. The rims yielded U-Pb ages $1236-827 \mathrm{Ma}$, if the more imprecise rims analyses are excluded, the rest plot yielded a zircon $\mathrm{U}-\mathrm{Pb}$ age of $1005.6 \pm 4.7 \mathrm{Ma}$ (MSWD=5.5), containing low $\mathrm{Th} / \mathrm{U}$ ratios from 0.80 to 0.23 . This calculated age probably corresponds to a Grenvillian metamorphism age that started at $c a .1 \mathrm{Ga}$ (Casquet et al., 2010), whereas the igneous protolith have crystallized in the Mesoproterozoic (1444 Ma).

Post-mineral rocks in gold-bearing quartz vein mineralization area. An equigranular quartz diorite (sample 75, table 1) from approximately $2.5 \mathrm{~km}$ southeast of the main quartz veins (Quebrada Ongoro, Fig. 2). Separated zircons are mostly $150 \mu \mathrm{m}$ in length, equant to slightly elongated, and sub-round in form. CL images display an oscillatory zoning (Fig. 4C), yielded a zircon U-Pb age of $198.3 \pm 1.3 \mathrm{Ma}$ based on fourteen of twenty zircon crystals, with $\mathrm{Th} / \mathrm{U}$ from 1.4 to 3 . Six crystals excluded from the age calculation; one zircon is very old, the textural features and isotopic measurements indicate this crystal is an inherited xenocryst dated at $1583 \pm 47 \mathrm{Ma}$, with a zircon $\mathrm{Th} / \mathrm{U}$ ratio (0.94), probably incorporated from the Arequipa Massif (Fig. 4C). The other sample of diorite (sample 82, table 1) from village of Angostura (Quebrada Tacya, Fig. 1). The zircons from this sample are sub-round to elongated grains (less than $120 \mu \mathrm{m}$ in length). The CL images show a slight oscillatory zoning towards the edges; many grains generally have clear cores. Based on ten spots of twenty grains analyzed, yielded a zircon $\mathrm{U}-\mathrm{Pb}$ age of $195.2 \pm 2.0 \mathrm{Ma}$, with zircon $\mathrm{Th} / \mathrm{U}$ ratios from 1 to 2.1. Ten spots analyses were excluded from the calculated age, as yielded discordant dates (Fig. 4D).

Zircon spot $\mathrm{U}-\mathrm{Pb}$ analyses from regional equigranular tonalite (sample 89, table 1), collected from village of Andamayo (Río Colca). Eight of twenty analyzed zircons yield an age of $182.3 \pm 1.7 \mathrm{Ma}$ (Fig. 4E).

\subsection{Zafranal porphyry copper}

The denomination of the different magmatic phases (precursor, pre-, inter-, and post-mineralization) were made during the geological mapping and drill-core logging stages, performed by geologists of AQM Peru S.A.C. and summarized by Tejada (2010), Fernandez-Baca (2011), Rivera et al. (2008, 2010), Rivera (2012a, b), and De Ruijter et al. (2013). This observation has allowed to obtain relative ages, and here were included the approximate duration of different porphyry bodies related to the copper mineralization in Zafranal, determined by using exclusively $\mathrm{U}-\mathrm{Pb}$ zircon dating.

Precursor pluton. A hypidiomorphic granular granodiorite (95A, Zafranal Super-unit) at the Zafranal porphyry district, taken from approximately $4 \mathrm{~km}$ east of the center Zafranal porphyry and $2.5 \mathrm{~km}$ northwest of the Santo Domingo mining (gold-bearing quartz veins). In general it consists of slightly NW elongated pluton (Fig. 1), which extends to Cerro Torconta and reach the south of Arequipa. Based on field relations, the granodiorite intruded to gneiss and early diorites. The zircons of granodiorite are elongate (less than $210 \mu \mathrm{m}$ in length) euhedral in shape. CL images show that most crystals with a prominent oscillatory zoning in the entire zircon population, but some few grains show core and rims with low-luminescence (Fig. 5A). The granodiorite yielded a U-Pb age of 183.0 $1.1 \mathrm{Ma}$ (Fig. 5A), based in eleven zircons of twenty points analyzed. Three spot analyses yielded younger dates (178 Ma), presumably due to $\mathrm{Pb}$ loss. The all crystal zircons analyzed display high-U (810$1900 \mathrm{ppm})$ and low $\mathrm{Th} / \mathrm{U}$ values $(0.5-0.8)$.

Early-mineral rocks. A quartz diorite porphyry (Q-DIO) at the Zafranal porphyry, taken from approximately $0.5 \mathrm{~km}$ east of the center of the porphyry copper (Fig. 3) present lower degree of hydrothermal alteration. The zircon crystals from this sample generally are clear and colorless and mostly elongate (less than $400 \mu \mathrm{m}$ in length) subrounded to euhedral in shape, this combination of zircon shape suggests relatively rapid to moderate crystallization with a high-level emplacement. The CL images reveal an ocillatory zoning and some irregular zoning, but one zircon xenocrystal has internal structure different from the remaining ninteen zircons. The xenocrystal has homogeneous $\mathrm{CL}$, with outermost invariably being a bright $\mathrm{CL}$ rim. Therefore, largely given the common nature of the zircon population. The quartz diorite porphyry, yielded a zircon U-Pb age 179.8 $\pm 1.2 \mathrm{Ma}$ (Fig. 5B), based on twelve of nineteen. Six zircons are younger due to $\mathrm{Pb}$ loss. The xenocrystal indentified in $\mathrm{CL}$ is much older, isotopic measurements indicate that it is an inherited xenocrystal dated at $1032 \pm 11 \mathrm{Ma}$, with low-U (350 ppm) a low- $\mathrm{Th} / \mathrm{U}$ ratio $(0.51)$, similar in age to those of the Arequipa Massif (Fig. 5B). 

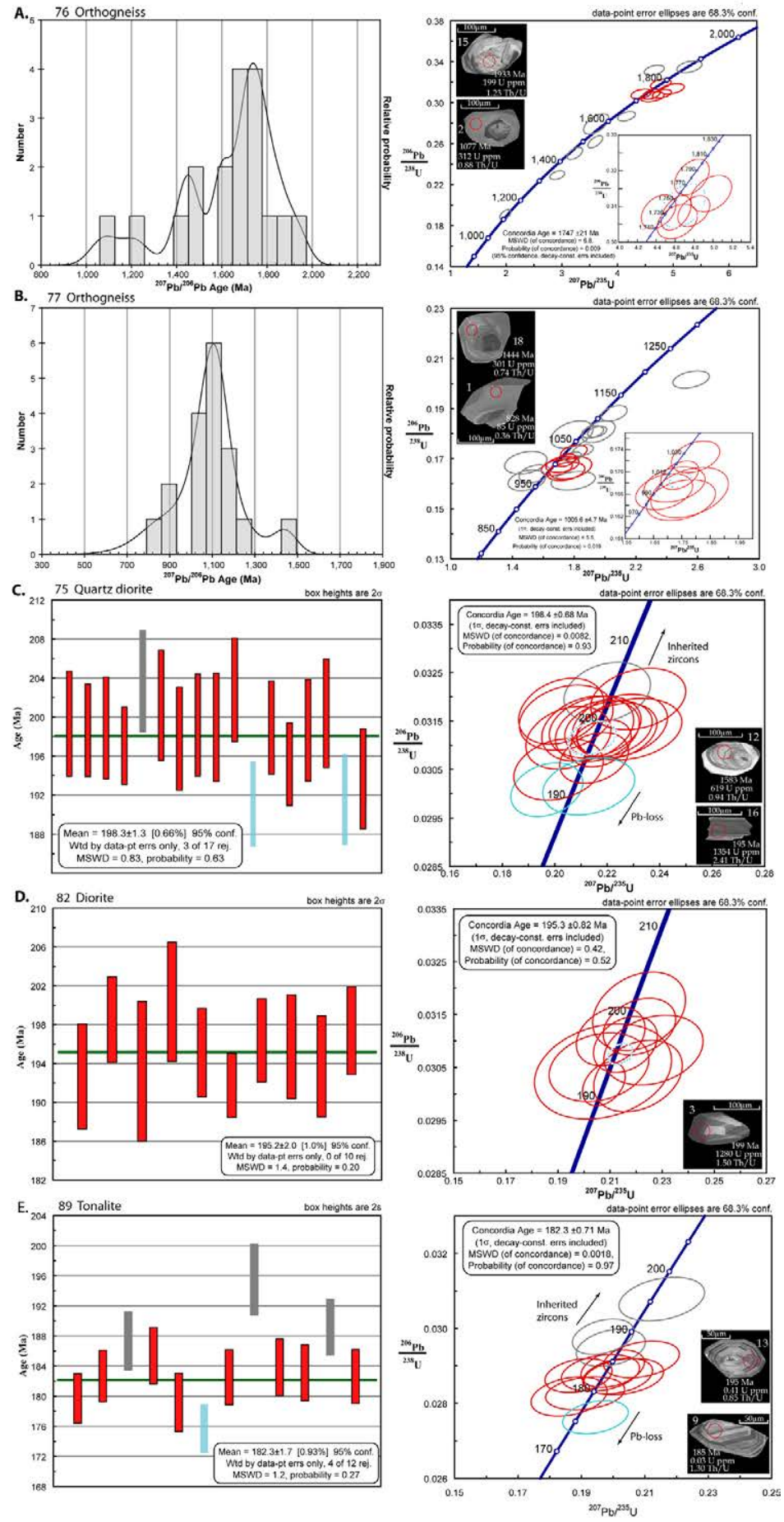

FIG. 4. U-Pb ages for samples from rocks associated with gold-bearing quartz veins at Copacabana mining distric. Ages are calculated based on the Concordia diagrams and weighted mean ${ }^{206} \mathrm{~Pb} /{ }^{238} \mathrm{U}$ ages histograms. Furthermore, ages distribution for metamorphic zircons (A and B) and Concordia diagram are shown, and for each sample one or more representative analyzed zircons. Histogram diagrams are also shown the distribution for $\mathrm{Pb}$ loss (sky-blue bars), and inheritance (gray color) in some of the analyzed zircons (C and E). A. 76: orthogneiss and B. 77: orthogneiss, both samples from Arequipa Massif. C. 75: quartz diorites and D. 82: diorite, both samples from Coastal Batholith (Punta Coles Super-unit). E. 89: tonalite from Coastal Batholith (Zafranal Super-unit). 

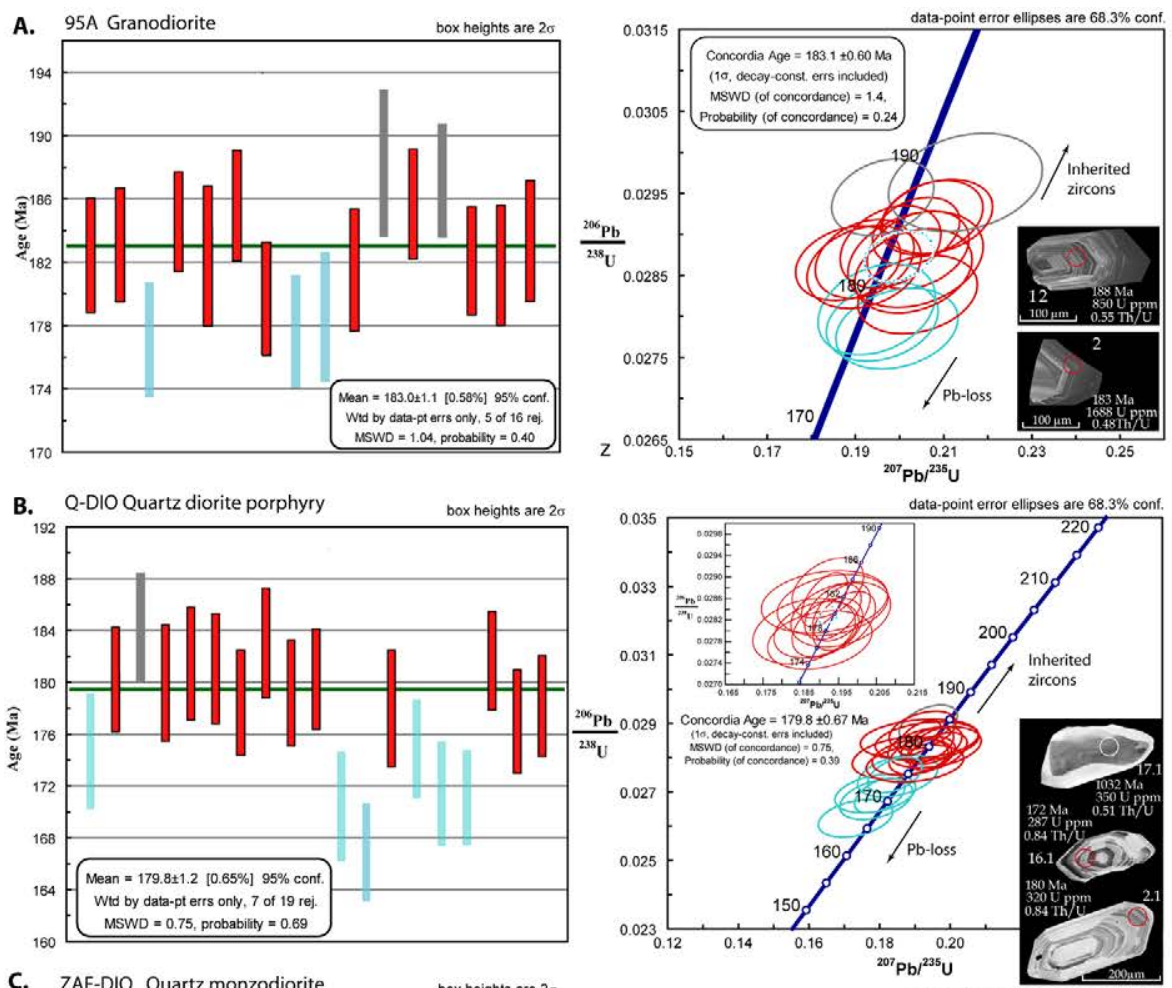

C. ZAF-DIO Quartz monzodiorite
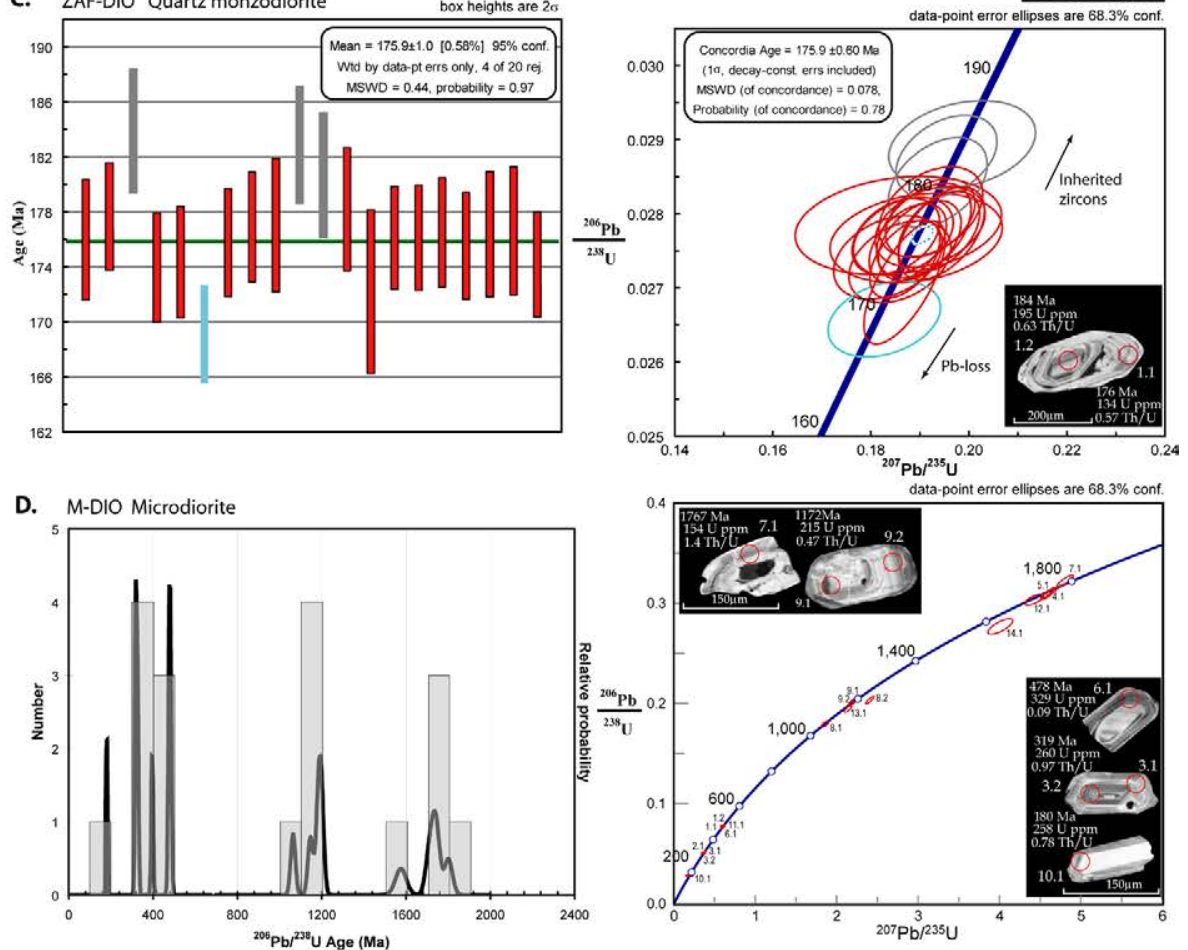

FIG. 5. U-Pb ages for rock samples from the Zafranal porphyry. Ages are calculated based on the Concordia diagrams and weighted mean ${ }^{206} \mathrm{~Pb} /{ }^{238} \mathrm{U}$ ages histograms. Furthermore, in histogram diagrams are also shown the distribution for $\mathrm{Pb}$ loss (sky-blue bars), and inheritance (gray bars) in some of the analyzed zircons (A, B, and C). A. 95A: granodiorite; B. Q-DIO: quartz diorite porphyry; C. ZAF-DIO: quartz monzodiorite and D. M-DIO: microdiorite. All samples from Coastal Batholith (Zafranal Super-unit). 
Inter-mineral porphyry 1 . The Zafranal quartzmonzodiorite porphyry (ZAF-DIO) from approximately $1 \mathrm{~km}$ east of the center of the main orebody (Fig. 3) pervasively hydrothermally altered and mineralized. The zircons from this sample are elongate to subround in shape and less than $300 \mu \mathrm{m}$ in length. CL images mainly show strong oscillatory zoning and irregular zoning. Other zircons display small relict cores, which are elongate euhedral prisms with oscillatory zoning surrounded by rim with resorption features. Rims show different orientation oscillatory zoning and are large enough to be analyzed (5C). Twenty-one points were analyzed including rims and cores. Three cores yielded U-Pb ages between 180-184 Ma, which are interpreted as the inherited zircons from the precursor pluton granodiorite (sample 95A). The analyzed rims yielded $\mathrm{U}-\mathrm{Pb}$ age of 176 Ma, very close to age established by the remaining sixteen zircons (175.9 Ma). One of the crystal give an age slightly younger (169 Ma). We interpret the statistically more robust and age of $175.9 \pm 1.0 \mathrm{Ma}$ to more accurately reflect the crystallization age for quartz-monzodiorite porphyry.

Inter-mineral porphyry 2 . The microdiorite (M-DIO) forms a second porphyry copper-related, from approximately $0.5 \mathrm{~km}$ from east part of the main porphyry body (Fig. 3). Microdiorite cut the Zafranal quartz-monzodiorite porphyry, and is characterized by showing a pervasive hydrothermal alteration, mineralization and dynamic metamorphism features. Zircons are elongate to sub-rounded (less than $150 \mu \mathrm{m}$ in length), subhedral in shape. The CL images reveal a varied internal structure and features (Fig. 5D). Some grains display small cores surrounded with mantle weak oscillatory zoning. Also commonly show crystals with prominent oscillatory zoning. Eighteen spots were analyzed on fourteen zircon grains, included rim and core. The cores do not show substantial variation in isotopic measurements in relation to the rims. The older population of zircons have a late Paleproterozoic ${ }^{206} \mathrm{~Pb} /{ }^{238} \mathrm{U}$ age of 1801-1710 Ma (four crystal zircons), whereas other zircons with more homogeneous rim area has a Mesoproterozoic ${ }^{206} \mathrm{~Pb} /{ }^{238} \mathrm{U}$ age of $1575-1064 \mathrm{Ma}$ (six crystal zircons). The other younger population of zircons with a marked oscillatory zoning. Three crystal zircons have an Ordovician (478-481 Ma) $\mathrm{U}-\mathrm{Pb}$ age. Four analyzed in three zircons have Devonian-Carboniferous U-Pb age of 396-319 Ma. Furthermore, one zircon yield an age of $179.7 \pm 3 \mathrm{Ma}$
(Fig. 5D), and therefore is interpreted as maximum crystallization age of the microdiorite.

\subsection{Late Jurassic}

Late intrusion. At Huano village, a granular tonalite (86, Torrecillas Super-unit). The zircons from this sample are slightly elongate to sub-round (less than $120 \mu \mathrm{m}$ in length), subhedral in shape. CL image show, some crystal highlights very high concentrations of $U$ in the crystal center, more moderate values in an intermediate shell and high concentrations in the rim. Twenty spots were analyzed including center and rim of zircons. Nine crystal center yielded U-Pb ages between 140-144 Ma, with very high $U$ concentrations of 2481-1000 ppm and also high $\mathrm{Th} / \mathrm{U}$ values of center (0.8-1.57). Eleven rims yielded U-Pb ages in 149-146 Ma, with $\mathrm{U}$ concentrations of $875-513 \mathrm{ppm}$ and $\mathrm{Th} / \mathrm{U}$ values between 0.61-0.94. If the less concordant analyses are excluded, the rest plot yielded a zircon $\mathrm{U}-\mathrm{Pb}$ age of $145.9 \pm 1.4 \mathrm{Ma}$ (Fig. 6).

\section{Discussion}

Four views emerge from the data obtained: 1. Arequipa Massif, 2. Early Jurassic arc extent of the Coastal Batholith, 3. Intrusive bodies associated with ore mineralization in the quartz veins and Zafranal porphyry deposit, and 4. late Jurassic magmatic pulse.

\subsection{Arequipa Massif}

Arequipa Massif includes rocks displaying protolith ages of $1.9 \mathrm{Ga}$ (Dalmayrac et al., 1977; Cobbing et al., 1977) and other rocks showing Mesoproterozoic protolith and metamorphism ages of 1.2-1.0 Ga (Wasteneys et al., 1995; Loewy et al., 2004). Along the Cincha-Lluta Fault System, the metamorphic rocks are thrusted over the Mesozoic series of the Western Peruvian Mesozoic Basin (Caldas, 1993; Carlotto et al., 2008, Fig. 1). The Arequipa Massif in this area contains Paleoproterozoic zircons (samples 76 and 77) and core zircons with rims plot on discordia resulting from $\mathrm{Pb}$-loss during Grenvillian metamorphism (Fig. 4A, B), similar to migmatitic gneisses of the Camaná-Mollendo domain, described by Casquet et al. (2010). This confirms the Arequipa Massif extent to the western flank of the Western Cordillera. 

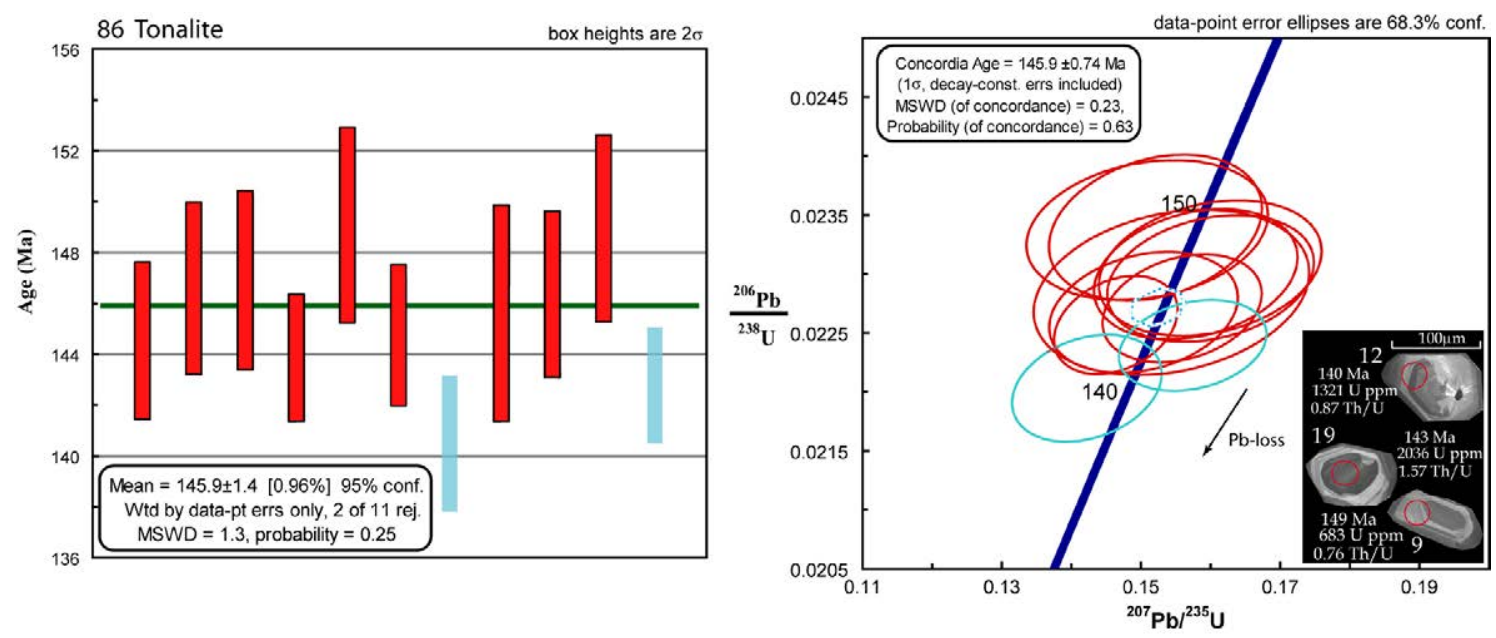

FIG. 6. U-Pb ages for rock samples from the Zafranal porphyry. Ages are calculated based on the Concordia diagrams and weighted mean ${ }^{206} \mathrm{~Pb} / 238 \mathrm{U}$ ages histograms. Furthermore, in concordia diagram is also shown representative analyzed zircons, and in histogram diagram is shown the distribution for $\mathrm{Pb}$ loss (sky-blue bars) in two of the analyzed zircon. (86) Tonalite from Coastal Batholith (Torrecillas Super-unit).

\subsection{Early Jurassic arc extent of the Coastal Batholith}

The $\mathrm{U}-\mathrm{Pb}$ ages reported herein of mafic and felsic intrusive rocks from Chuquibamba to Arequipa in southern Peru (Fig. 1, Coastal Batholith), shows that first magmatic activities occurred during 200-174 Ma.

For the magmatic belt in the study area (Fig. 1) Cordani et al. (1985) indicated an early Jurassic $\mathrm{K}-\mathrm{Ar}$ ages (189 $\pm 11 \mathrm{Ma})$, which is considered as the minimum age of the tectonomagmatic process. Later, Mukasa (1986) published two early Jurassic $\mathrm{U}-\mathrm{Pb}$ ages (188 and $184 \mathrm{Ma}$ ) from northwest of Arequipa. He indicated that these rocks represent the plutonic substructure of a Jurassic continental arc of unknown extent. In the south of Arequipa, Demouy et al. (2012) got new U-Pb ages for gabbros-diorites, which restricted early Jurassic age (200-175 Ma) to a mafic magmatism (Fig. 1). Our results show that the first magmatic activity in this study area occurred during 198.3-195.2 Ma (Sinemurian; Fig. 4C, D), and is associated with diorite-quartz diorite rocks of Punta Coles Superunit (Table 1). A second magmatic phase encloses tonalite-granodiorite rocks (Table 1) emplaced at 183.0-175.9 Ma (Pliensbachian-Toarcian; Figs. 4E and 5) of Zafranal Super-unit. The second magmatic phase include small microdiorites, quartz diorites and quartz monzodiorite porphyritic stocks and dikes (Table 1) with an EW-trend at 179.8-175.9 Ma (Fig. 5B, C). The two magmatic suites make up a thin magmatic belt $(15 \times 130 \mathrm{~km})$ that extends from southern Chuquibamba to the southern Arequipa (Fig. 1)

\subsection{Intrusive associated with gold-bearing quartz veins and Zafranal porphyry deposit}

\subsubsection{Gold-bearing quartz vein mineralization}

The gold-bearing quartz vein systems in Copacabana and Rinconada de Chapi mining districts have metamorphic and volcano-sedimentary host rocks, respectively. Early diorites (198.3-195.2 Ma; Fig. 2) of Punta Coles Super-unit intruded the metamorphic host rocks of the gold-bearing quartz veins and restrict their extent (Cerro Gandolfo, Fig. 2). Therefore it is inferred that the gold-bearing quartz veins were formed before $c a$. 198.3 Ma.

\subsubsection{Zafranal porphyry deposit}

The first radiometric ages for the Zafranal porphyry copper deposit were published by Rivera (2012a), who reported ${ }^{40} \mathrm{Ar} /{ }^{39} \mathrm{Ar}$ plateau ages for hydrothermal biotite of $82.41 \pm 0.43 \mathrm{Ma}$ from Zafranal diorite and $83.37 \pm 0.54$ and $81.16 \pm 0.43 \mathrm{Ma}$ from microdiorite. According to this author, the Zafranal diorite and microdiorite are associated with copper mineralization, and he concluded that the alteration and mineralization developed in the late 
Cretaceous. However, the ${ }^{40} \mathrm{Ar} /{ }^{39} \mathrm{Ar}$ ages for Zafranal hydrothermal biotites only record cooling under $320 \pm 30^{\circ} \mathrm{C}$; biotite closure temperature estimated using Dodson (1973) and parameters presented by Harrison et al. (1985) and McDougall and Harrison (1999). Whether this thermal event was related or not to the hydrothermal copper mineralization of Zafranal is considered uncertain here, as no other, isotopic data are available for constraint ore formation. While, the use of Zircon U-Pb dating from intrusions associated with porphyry copper mineralization makes possible to us confidently assign crystallization ages to the various intrusive units, as zircon has the highest known closure temperature for $\mathrm{Pb}$ diffusion, which exceeds $900^{\circ} \mathrm{C}$ for zircons of typical sizes (Cherniak and Watson, 2000, and references therein). At Zafranal, three phases of porphyry intrusions were dated by U-Pb, with the oldest being the granodiorite precursor batholith at $183.0 \pm 1.1 \mathrm{Ma}$. The second phase is a quartz diorite intrusion at $179.8 \pm 1.2 \mathrm{Ma}$, and the third phase is a quartz monzodiorite at $175.9 \pm 1.0 \mathrm{Ma}$ (Fig. 7). As the multiphase porphyry complex at Zafranal is hosting a copper mineralized stockwork, we postulate that copper mineralization also was introduced during the early Jurassic, while the late Cretaceous ${ }^{40} \mathrm{Ar} /{ }^{39} \mathrm{Ar}$ biotite ages of Rivera (2012a) represent a thermal overprint, which could be either a late hydrothermal activity or just heating by Cretaceous magmatic processes of the Arequipa Segment of Coastal Batholith of Peru (i.e., Demouy et al., 2012).

\subsubsection{Late Jurassic}

Cordani et al. (1985) reported a K-Ar age of late Jurassic intrusion east of the CLFS $(157 \pm 14 \mathrm{Ma})$. Later Demouy et al. (2012) published a late Jurassic age (U-Pb, 154.7 $\pm 1.0 \mathrm{Ma}$ ) for a monzonite sill from the south of Arequipa, which is associated with sedimentary formations without any presence of magmatic activity between 160.5 to 90 Ma. However, our data set combined with the recently published U-Pb ages (Santos et al., 2016), show that two late Jurassic magmatic events developed west of the CLFS, and cover a wide area west of Chuquibamba (Fig. 1). First magmatic activity occurred during $158-157 \mathrm{Ma}$ (Oxfordian), containing biotite-rich granodiorite and granite-monzogranite rocks of Tembladera and Chillihuay units, respectively. A second magmatic phase encloses amphibole-rich tonalite rocks emplaced at $145.9 \mathrm{Ma}$ (Tithonian) of Torrecillas Super-unit. Both magmatic events probably ended with injection of copper mineralizing fluid (e.g., Tinajas prospect $152 \mathrm{Ma}$ and Campanero prospect $141 \mathrm{Ma}$, Fig. 1).

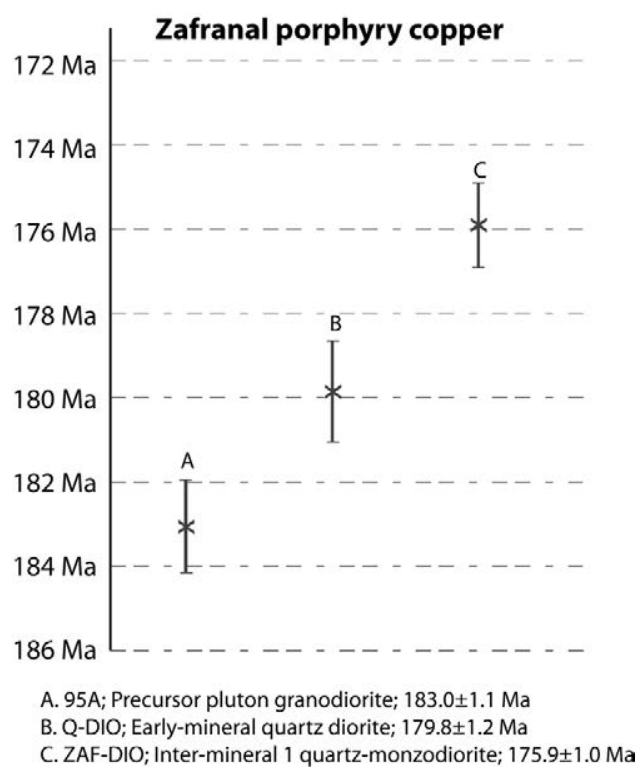

FIG. 7. Summary of magmatic ages determined at Zafranal porphyry copper based on weighted mean averages of ${ }^{207} \mathrm{~Pb}-\mathrm{corrected}$ ${ }^{206} \mathrm{~Pb} /{ }^{238} \mathrm{U}$ spot ages using SHRIMP and LA-ICP-MS. Errors shown at $2 \sigma$ levels. 
Overall, our geochronology data coincide with the first magmatic pulse from 200-175 Ma previously identified in the southern sector of the Arequipa Segment of the Coastal Batholith of Peru by Demouy et al. (2012). Later the early Jurassic arc was overprint by felsic Cretaceous intrusive bodies (90-60 Ma, Demouy et al., 2012), hence the biotites of some early Jurassic rocks register the thermal overprint of these two main magmatic pulses (e.g., Zafranal porphyry copper).

\section{Conclusions}

Outcrops of metamorphic rocks in Western Cordillera (Western Peruvian Mesozoic Basin) correspond to Arequipa Massif with Paleoproterozoic igneous protolith and Mesoproterozoic Grenville-age metamorphism $(1.75 \mathrm{Ga}$ and $1 \mathrm{Ga})$.

The Coastal Batholith exposed in the study area, along the fault-bounded thin magmatic belt $(<15 \mathrm{~km}$ wide) was emplaced into Arequipa Massif during the early Jurassic. Two main magmatic events are identified: (1) Early mafic magmatic event from ca. 200-194 Ma that correspond to the Punta Coles Super-unit (200-188 Ma). It consists mainly of diorites and quartz diorites, and (2) A second event of dominantly felsic magmatism from $c a$. 184$175 \mathrm{Ma}$ that corresponds to the Zafranal Super-unit (188-176 Ma). The porphyritic stocks with copper mineralization at Zafranal crystallized from 181 to $175 \mathrm{Ma}$ and provide a maximum age for the hydrothermal processes.

Late Jurassic magmatic events comprised of granodiorites and granitic-monzogranitic bodies emplaced from 158 to $157 \mathrm{Ma}$, which correspond to Tembladera and Chillihuay units. A late magmatic phase encloses tonalite plutonics emplaced at $c a$. 145.9 Ma, corresponding to Torrecillas Super-unit (150-145 Ma).

Mineralizing processes in this area occurred in the early Jurassic. Gold-bearing quartz vein mineralization formed in early stages of the Coastal batholith (>200 Ma), while copper minerals in the Zafranal porphyritic host rocks may have been introduced from 181.1 to $174.7 \mathrm{Ma}$. A late Cretaceous thermal event registered by biotite with ${ }^{40} \mathrm{Ar} /{ }^{39} \mathrm{Ar}$ age from 83 to $81 \mathrm{Ma}$ (previously considered as the mineralizing event) constitutes just a thermal, overprint, which could be either a late hydrothermal alteration or a local heating from an unidentified magmatic source. Overall, much of copper mineralization in this area is thought to be linked to the last stages of each magmatic suite (e.g., Zafranal, Tinajas and Campanero).

\section{Acknowledgments}

We wish to express our gratitude to INGEMMET and AQM Peru Copper S.A.C. for the support in the logistics of obtaining the Coastal Batholith samples and information generated during their exploration stages in the Zafranal cluster. John Cervantes and Paola LLamoca of Regional Geology from Geological Survey of Peru (INGEMMET) have greatly helped with this project. This work is part of the master thesis of the first author, with the support of the high-resolution geochronology laboratory of the Institute of Geosciences of the University of Sao Paulo-Brazil and Laboratory of China University of Geosciences (Wuhan).

\section{References}

Acosta, J.; Sempere, T. 2017. Evolución tectónica y metalogénesis del Perú. In Congreso Internacional de Prospectores y Exploradores, No. 10, Instituto de Ingenieros de Minas del Perú, Abstract: 2-7. Lima.

Allmendinger, R.W.; Jordan, T.E.; Kay, S.M.; Isacks, B.L. 1997. The evolution of the Altiplano-Puna plateau of the Central Andes. Annual Review of Earth and Planetary Sciences 25: 139-174.

Atherton, M.; Pitcher, W.; Warden, V. 1983. The Mesozoic marginal basin of central Peru. Nature 305: 303-305.

Atherton, M.; Warden, V.; Sanderson, L.M. 1985. The Mesozoic marginal basin of central Peru: A geochemical study of within plate-edge volcanism. In Magmatism at a plate edge: The Peruvian Andes: Glasgow, Blackie (Pitcher, W.S.; Atherton, M.P.; Cobbing, E.J.; Beckinsale, R.D.; editors). John Wiley and Sons: 47-58.

Bahlburg, H.; Carlotto, V.; Cárdenas, J. 2006. Evidence of Early to Middle Ordovician arc volcanism in the Cordillera Oriental and Altiplano of southern Peru, Ollantaytambo Formation and Umachiri beds. Journal of South American Earth Sciences 22: 52-65.

Beckinsale, R.D.; Sánchez, A.; Brook, M.; Cobbing, E.J.; Taylor, W.P.; Moore, N.D. 1985. Rb-Sr wholerock isochron and $\mathrm{K}$-Ar age determinations for the Coastal Batholith of Peru. In Magmatism at a plate edge: the Peruvian Andes (Pitcher, M.P.; Cobbing, E.J.; Beckinsale, R.D.; editors). Blackie Halsted: 177-202. London.

Benavides, V. 1956. Cretaceous system in northern Peru. Bulletin of American Natural History 108: 252-494. 
Benavides, V. 1962. Estratigrafía Pre-terciaria de la región de Arequipa. In Congreso Nacional de Geología, No. 2. Boletín de la Sociedad Geológica del Perú 38: 5-63. Lima.

Benavides. V. 1999. Orogenic evolution of the Peruvian Andes: The Andean cycle. Special Publication 7: 61-107.

Boeckhout, F. 2012. Geochronological constraints on the Paleozoic to early Mesozoic geodynamic evolution of southern coastal Peru. Ph.D. Thesis (Unpublished). University Genève: $176 \mathrm{p}$.

Boily, M.; Brooks, C.; Ludden, J.N. 1989. Chemical and isotopic evolution of the Coastal Batholith of southern Peru. Journal of Geophysical Research 94: 483-498.

Caldas, J. 1993. Geología de los cuadrángulos de Huambo y Orcopampa (Hojas 32r y 31r). Instituto Geológico Minero y Metalúrgico, Boletín Serie A: 62 p. Lima.

Camus, F. 2003. Geología de los sistemas porfíricos en los Andes de Chile. Servicio Nacional de Geología y Minería: 267 p.

Carlotto, V.; Cárdenas, J.; Carlier, G. 2008. The lithosphere of Southern Peru: A result of the accretion of allochthonous blocks during the Mesoproterozoic. In International Symposium on Andean Geodynamics, No. 7, Extended Abstract: 105-108.

Carlotto, V.; Quispe, J.; Acosta, H.; Rodríguez, R.; Romero, D.; Cerpa, L.; Mamani, M.; Díaz, E.; Navarro, P.; Jaimes, F.; Velarde, T.; Lu, S.; Cueva, E. 2009a. Dominios geotectónicos y Metalogénesis del Perú. Boletín de la Sociedad Geológica del Perú 103: 1-89.

Carlotto, V.; Rodríguez, R.; Acosta, H.; Cárdenas, J.; Jaillard, E. 2009b. Alto estructural Totos-Paras (Ayacucho): límite paleogeográfico en la evolución mesozoica de las cuencas Pucará (Triásico superior-Liásico) y Arequipa (Jurásico-Cretácico). Boletín de la Sociedad Geológica de Perú, Volumen especial Víctor Benavides Cáceres 7: $1-46$.

Casquet, C.; Fanning, C.; Galindo, C.; Pankhurst, R.; Rapela, C.; Torres, P. 2010. The Arequipa Massif of Peru: new SHRIMP and isotope constraints on a Paleoproterozoic inlier in the Grenvillian orogeny. Journal of South American Earth Science 29: 128-142.

Cherniak, D.J.; Watson, E.B. 2000. Pb diffusion in zircon. Chemical Geology 172: 5-24.

Chew, D.M.; Schaltegger, U.; Kosler, J.; Whitehouse, M.J.; Gutjahr, M.; Spikings, R.A.; Miskovic, A. 2007. $\mathrm{U}-\mathrm{Pb}$ geochronologic evidence for the evolution of the Gondwanan margin of the north-central Andes. Geological Society of America Bulletin 119 (5): 697-711.
Chew, D.M.; Magna, T.; Kirkland, C.L.; Miskovic, A.; Cardona, A.; Spikings, R.; Schaltegger, U. 2008. Detrital zircon fingerprint of the Proto-Andes: evidence for a Neoproterozoic active margin? Precambrian Research167 (1-2): 186-200.

Clark, A.H. 1993. Are outsize porphyry copper deposits either anatomically or environmentally distinctive? Society of Economic Geologists Special Publication 2: 213-282.

Clark, A.H.; Farrar, E.; Kontak, D.J.; Langridge, R.J.; Arenas, F.; M.J., France, L.J.; McBride, S.L.; Woodman, P.L.; Wasteneys, H.A.; Sandeman, H.A.; Archibald, D.A. 1990a. Geologic and geochronologic constraints on the metallogenic evolution of the Andes of southeastern Peru. Economic Geology 85: 1520-1583.

Clark, A.H.; Tosdal, R.M.; Farrar, E.; Plazolles, V.A. 1990b. Geomorphologic environment and age of supergene enrichment of the Cuajone, Quellaveco, and Toquepala porphyry copper deposits, southeastern Peru. Economic Geology 85: 1604-1628.

Cobbing, E.J.; Pitcher, W.S. 1972. Plate tectonics and the Peruvian Andes. Nature 246: 51-53.

Cobbing, E.J.; Pitcher, W.S.; Taylor, W.P. 1977. Segments and super-units in the Coastal Batholith of Peru. Journal of Geology 85: 625-631.

Coira, B.; Davidson, J.; Mpodozis, C.; Ramos, V. 1982. Tectonic and magmatic evolution of the Andes of northern Argentina and Chile: Earth Science Reviews 18: 302-332.

Cordani, U.G.; Kawashita, K.; Siegl, G.G.; Vicente, J.C. 1985. Geochronological results from the southeastern part of the Arequipa massif. Comunicaciones 35: 45-51.

Couch, R.; Whitsett, R.; Huehn, B.; Briceno-Guadalupe, L. 1981. Structures of the continental margin of Peru and Chile. Geological Society of America 154: 703-726.

Dalmayrac, B.; Lancelot, J.R.; Leyreloup, A. 1977. Two-billion-year granulites in the Late Precambrian metamorphic basement along the Southern Peruvian coast. Science 198: 49-51.

Davidson, J.; Mpodozis, C. 1991. Regional geologic setting of epithermal gold deposits, Chile. Economic Geology 86: 1174-1186.

De Ruijter, M.A.; Mosher, G.Z.; Ghaffari, H.; DanonSchaffer, M.; Hafez, S.A.; Guzman, C.; Muir, W. 2013. Technical report and preliminary assessment of the Zafranal project, Peru. AQM Copper Inc.: 256 p.

Demouy, S.; Paquette, J.; De Saint Blanquat, M.; Benoit, M.; Belousova, E.; O'Reilly, S.; Garcia, F.; Tejada, L.; Gallegos, R.; Sempere, T. 2012. Spatial and temporal evolution of liassic to Paleocene arc activity in Southern 
Peru un raveled by zircon $\mathrm{U}-\mathrm{Pb}$ and $\mathrm{Hf}$ in situ data on plutonic rocks. Lithos 155: 183-200.

Dodson, M.H. 1973. Closure temperature in cooling geochronological and petrological systems. Contributions to Mineralogy and Petrology 40: 259-274.

Fernandez-Baca, A. 2011. El pórfido de cobre-oro Zafranal. In Congreso Internacional de Prospectores y Exploradores, No. 7, Abstract, CD-ROM: 4 p. Lima.

Gustafson, L.B.; Hunt, J.P. 1975. The porphyry copper deposit at El Salvador, Chile. Economic Geology 70: 857-912. doi: 10.2113/gsecongeo.70.5.857.

Harrison, T.M.; Duncan, I.; McDougall, I. 1985. Diffusion of ${ }^{40} \mathrm{Ar}$ in biotite: temperature, pressure and compositional effects. Geochimica et Cosmochimica, Acta 49: 2461-2468.

Hoskin, P.W.O.; Schaltegger, U. 2003. The Composition of Zircon and Igneous and Metamorphic Petrogenesis. Reviews in Mineralogy and Geochemistry 53: 27-62.

Huamán, C.; Bustamante, J.; Gálvez, S. 2014. Mineralización supérgena del pórfido $\mathrm{Cu}-\mathrm{Au}-\mathrm{Mo}$, Proyecto Ocaña, Arequipa-Perú. In Congreso Peruano de Geología, No. 17, Resúmenes extendidos: 4 p. Lima.

INGEMMET. 2001. Mapa Geológico del cuadrángulo de Chuquibamba, scale 1:100 000, Lima.

Isacks, B.L. 1988. Uplift of the central Andean plateau and bending of the Bolivian orocline. Journal of Geophysical Research 93: 3211-3231.

Jacay, J.; Semperé, T.; Husson, L.; Pino, A. 2002. Structural characteristics of the Incapuquio Fault System, southern Peru. In International Symposium on Andean Geodynamics, No. 5, Extended Abstracts: 319-321. Toulouse.

Jaillard, E. 1992. La fase peruana (Cretácico superior) en la margen peruana. Boletín de la Sociedad Geológica del Perú 83: 81-87.

James, D.E. 1971. Plate Tectonic Model for the Evolution of the Central Andes. Geological Society of America Bulletin 82: 3325-3346.

Jenks, W.F.; Harris, E.G. 1953. Plutonics near Arequipa as a petrologic sample of the Coastal Batholith in Peru. Boletín de la Sociedad Geológica del Perú 26: 79-94.

JICA (Japan International Cooperation Agency). 1986. Report on mineral exploration in Cotahuasi area, Republic Peru. Phase I. Metal Minig Agency of Japan: 223 p.

Kretz, R. 1983. Symbols for rock-forming minerals. American Mineralogist 68: 277-279.

Liu, Y. 2011. Guide Book for ICPMSDataCal. China University of Geosciences, China. State Key Laboratory of Geological Processes and Mineral Resources: 32 p.
Loewy, S.L.; Connelly, J.N.; Dalziel, I.W. 2004. An orphaned block: The Arequipa-Antofalla basement of the Central Andean margin of South America. Geological Society of America Bulletin 116: 171-187.

Lowell, J.D.; Guilbert, J.M. 1970. Lateral and vertical alteration-mineralization zoning in porphyry ore deposits: Economic Geology 65: 373-408.

Ludwig, K.R. 2001. User's manual for Isoplot/ex Version 2.49. A Geochronological Toolkit for Microsoft Excel. Berkeley Geochronological Center, Special Publication 1a: 1-55.

Martínez, W.; Cervantes, J. 2003. Rocas ígneas en el sur del Perú: nuevos datos geocronométricos, geoquímicos y estructurales entre los paralelos $16^{\circ}$ y $18^{\circ} 30^{\prime} \mathrm{S}$. Boletín del Instituto Geológico Minero y Metalúrgico (INGEMMET) 26, Serie D (Estudios Regionales): 140 p. Lima.

McDougall, I.; Harrison, T.M. 1999. Geochronology and Thermochronology by the ${ }^{40} \mathrm{Ar} /{ }^{39} \mathrm{Ar}$ Method. Oxford University Press: 269 p. New York.

Mukasa, S.B. 1986. Zircon U-Pb ages of super-units in the Coastal batholith, Peru: Implications for magmatic and tectonic processes. Geological Society of America Bulletin 97: 241-254.

Mukasa, S.B.; Henry, D.J. 1990. The San Nicolas batholith of coastal Peru: early Palaeozoic continental arc or continental rift magmatism? Journal of the Geological Society 147: 27-39.

Noury, M.; Philippon, M.; Bernet, M.; Paquette, J-L.; Sempere, T. 2017. Geological record of flat slabinduced extension in the southern Peruvian forearc. Geological Society of America 45: 723-726.

Oncken, O.; Hindle, D.; Kley, J.; Elger, K.; Victor, P.; Schemmann, K. 2006. Deformation of the Central Andean upper plate system-Facts, Fiction, and constrains for the plateau models. In The Andes, Active Subduction Orogeny (Oncken, O.; Franz, G.; Giese, P.; Götze, H.; Ramos, V.; Strecker, M.; Wigger, P.; editors). Springer-Verlag Berlin Heidelberg: 1-27.

Perelló, J.; Carlotto, V.; Zárate, A.; Ramos, P.; Posso, H.; Neyra, C.; Caballero, A.; Fuster, N.; Muhr, R. 2003. Porphyry-style alteration and mineralization of the middle Eocene to early Oligocene AndahuaylasYauri belt, Cuzco region, Peru. Economic Geology 98: 1575-1605.

Petford, N.; Atherton, M. 2003. Rifting, insertical magmatism and continental arc construction, Peru. American Geophysical Union, Fall Meeting, Abstract: V41A-04. Pitcher, W.S. 1985. A multiple and composite batholith. In Magmatism at a plate edge: The Peruvian Andes 
(Pitcher, M.P.; Cobbing, E.J.; Beckinsale, R.D.; editors). Blackie Halsted, London: 93-101.

Quang, C.X.; Clark, A.H.; Lee, J.K.W.; Guillén B.J. 2003: ${ }^{40} \mathrm{Ar} /{ }^{39} \mathrm{Ar}$ ages of hypogene and supergene mineralization in the Cerro Verde-Santa Rosa porphyry Cu-Mo cluster, Arequipa, Peru. Economic Geology 98: 1683-1696.

Quang, C.X.; Clark, A.H.; Lee, J.K.W. 2005. Response of Supergene processes to Episodic Cenozoic uplift, pediment erosion, and ignimbrite eruption in the porphyry copper province of southern Peru. Economic Geology 100: 87-114.

Ramos, V.A. 2008. The basement of the Central Andes: the Arequipa and related terranes. Annual Review of Earth and Planetary Sciences 36: 289-324.

Ramos, V.A.; Aleman, A. 2000. Tectonic Evolution of the Andes (Cordani, U.G.; Milani, E.J.; Thomaz Filho, A.; Campos, D.A; editors). In Tectonic Evolution of South America. International Geological Congress, No. 31, Special Publication: 635-685. Rio de Janeiro.

Reitsma, M.J. 2012. Reconstructing the Late Paleozoic: Early Mesozoic plutonic and sedimentary record of south-east Peru: Orphaned back-arcs along the western margin of Gondwana. Ph.D. Thesis (Unpublished). Université de Genève: 246 p.

Rivera, F.; Moretti, A.; Baumgartner, R. 2008. La franja Cretácea de pórfidos de cobre en el sur del Perú. In Congreso Peruano de Geología, No. 14. Resúmenes extendidos: 6 p. Lima.

Rivera, F.; León, J.; Cano, O.; Huamán, M. 2010. Controles de mineralización en el pórfido de $\mathrm{Cu}$ Zafranal, en el sur de Perú. In Congreso Peruano de Geología, No. 1, Resúmenes extendidos: 4 p. Lima.

Rivera, F. 2012a. Geología y geocronología del pórfido de $\mathrm{Cu}-\mathrm{Au}$ Zafranal, en el sur del Perú. In Congreso Peruano de Geología, No. 16, Resúmenes extendidos: 6 p. Lima.

Rivera, F. 2012b. Nuevos Datos Geocronológicos en la Franja Cretácea de Pórfidos de Cobre en el Sur del Perú. Sociedad Geológica del Perú, Boletín 106: 49-57.

Romero, D.; Ticona, P. 2003. Memoria descriptiva de la revisión y actualización del cuadrángulo de Huambo (Hoja 32r), Instituto Geológico Minero y Metalúrgico: 28 p. Lima, Perú.

Roperch, P.; Sempere, T.; Macedo, O.; Arriagada, C.; Fornari, M.; Tapia, C.; García, M.; Laj, C. 2006. Counterclockwise rotation of late Eocene-Oligocene forearc deposits in southern Peru and its significance for oroclinal bending in the central Andes. Tectonics, American Geophysical Union (AGU) 25 (3): TC3010.
Sandeman, H.A.; Clark, A.H.; Farrar, E. 1995. An integrated tectonomagmatic model for the evolution of the southern Peruvian Andes (13-20 $\mathrm{S}$ ) since $55 \mathrm{Ma}$. International Geology Review 37: 1039-1073.

Santos, A.; Weimin, G.; Tassinari, C.; Soberon, D.; Ccallo, W. 2016. Geocronología U-Pb sobre zircones en la contrastación de la evolución espacial-temporal del magmatismo y la metalogenia del Batolito de la Costa "segmento Arequipa". In Congreso Peruano de Geología, No. 18. Resúmenes extendidos: 4 p. Lima.

Sato, K.; Tassinari, C.C.G.; Basei, M.A.S.; Siga, J.O.; Onoe, A.T.; De Souza, M.D. 2014. Sensitive HighResolution Ion Microprobe (SHRIMP IIe/MC) of the Institute of Geosciences of the University of Sao Paulo, Brazil. Geologia USP. Série Científica 14 (3): 3-18.

Schildgen, T.; Ehlers, T.; Whipp, D.; Van Soest, M.; Whipple, K.; Hodges, K. 2009. Quantifying canyon incision and Andean Plateau surface uplift, southwest Peru: a thermochronometer and numerical modeling approach. Journal of Geophysical Research 114: 1-22.

Seedorff, E.; Dilles, J.H.; Proffett, J.M.; Einaudi, M.T.; Zurcher, L.; Stavast, W.J.A.; Johnson, D.A.; Barton, M.D. 2005. Porphyry deposits: Characteristics and origin of hypogene features. Economic Geology Anniversary 100: 251-298.

Shackleton, R.M.; Ries, A.C.; Coward, M.P.; Cobbold, P.R. 1979. Structure, metamorphism and geochronology of the Arequipa massif of Coastal Peru. Journal of the Geological Society 136: 195-214. London. doi: 10.1144/gsjgs.136.2.0195.

Siivola, J.; Schmid, R. 2007. List of mineral abbreviation. In Metamorphic Rocks. A Classification and Glossary of Terms. Cambridge University Press: 93-110.

Sillitoe, R.H.; Thompson, F.H. 1998. Intrusion-Related Vein Gold Deposits: Types, Tectono-Magmatic Settings and Difficulties of Distinction from Orogenic Gold Deposits: Resource Geology 48: 237-250.

Sillitoe, R.H.; Perelló, J. 2005. Andean Copper Province: Tectonomagmatic Setting, Deposit Types, Metallogeny, Exploration and Discovery. Economic Geology, Anniversary 100: 845-890.

Sillitoe, R.H. 2010. Porphyry Copper System. Economic Geology 105: 3-41. doi: 10.2113/gsecongeo.105.1.3.

Sillitoe, R.H. 2003. Iron oxide-copper-gold deposits an Andean view. Mineralium Deposita 38: 787-812.

Simmons, A.T.; Tosdal, R.M.; Wooden, J.L.; Mattos, R.; Concha, O.; McCracken, S.; Beale, T. 2013. Punctuated magmatism associated with porphyry $\mathrm{Cu}$-Mo formation in the Paleocene to Eocene of Southern Peru: Economic Geology 108: 625-639. 
Sobolev, S.V.; Babeyko, A.Y. 2005. What drives orogeny in the Andes? Geological Society of America Bulletin 33 (8): 617-620.

Stewart, J.W.; Evernden, J.F.; Snelling, N.J. 1974. Age determinations from Andean Peru: a reconnaissance survey. Geological Society of America Bulletin 85: 1107-1116.

Streckeisen, A.L. 1973. Plutonic rocks: Classification and Nomeclature Recommended by the I.U.G.S. Subcommission on the Systematics of Igneous. Rocks, Geotimes 18: 26-30.

Tejada, W. 2010. The Zafranal Cu Discovery. In Congreso Internacional de Prospectores y Exploradores, No. 6, Abstract CD-ROM: 2 p.

Thorpe, R.S. 1984. The tectonic setting of active Andean volcanism: In Andean Magmatism (Harmon, R.S.; Barreiro, B.A.; editors). Birkhäuser Boston: 4-8.

Tosdal, R.M.; Farrar, E.; Clark, A. 1981. K-Ar geochronology of the late Cenozoic volcanic rocks of the Cordillera Occidental, southernmost Peru. Journal of Volcanology and Geothermal Research 10 (1-3): 157-173. doi: 10.1016/0377-0273(81)90060-3.

Tosdal, R.M.; Clark, A.H.; Farrar, E. 1984. Cenozoic polyphase landscape and tectonic evolution of the Cordilleran Occidental, southernmost Peru: Geological Society of America Bulletin 95: 1318-1332.

Vargas, L. 1970. Geología del Cuadrángulo de Arequipa (Hoja 33s). Servicio de Geología y Minería de Perú (actualmente el Instituto Geológico Minero y Metalúrgico
(INGEMMET), Carta Geológica Nacional 24, Serie A: $64 \mathrm{p}$.

Vicente, J.C.; Sequeiros, F.; Valdivia, S.; Zavala, J. 1979. El sobre-escurrimiento de Cincha-Lluta: element del accidente mayor Andino al NW de Arequipa. Boletín de la Sociedad Geológica del Perú 61: 67-99.

Vicente, J.C. 1989. Early late Cretaceous overthrusting in the Western Cordillera of southern Peru. In Geology of the Andes and its relations to hydrocarbon and mineral resources (Ericksen, G.E.; Cañas, M.T.; Reinemund, J.A.; editors). Circum-Pacific Council for Energy and Mineral Resources Earth Science Series 11: 91-117. Houston, Texas.

Wasteneys, H.; Clark, A.; Farrar, E.; Langridge, R. 1995. Grenvillian granulite-facies metamorphism in the Arequipa Massif, Peru: a Laurentia-Gondwana link. Earth and Planetary Science Letters 132 (1-4): 63-73.

Weibel, M.; Frangipane-Gysel, M.; Hunziker, J.C. 1978. Ein Beitrag zur Vulkanologie Süd-Perus: Geologische Rundschau 67: 243-252.

Wilson, J.; García, W. 1962. Geología de los Cuadrángulos de Pachía y Palca (36v y 36x), Boletín Serie A: Comisión de la Carta Geológica Nacional: 81 p. Lima.

Wipf, M. 2006. Evolution of the Western Cordillera and Coastal Margin of Peru: Evidence from Lowtemperature Thermochronology and Geomorphology. Ph.D. Thesis (Unpublished). Swiss Federal Institute of Technology Zürich: 163 p.

Manuscript received: March 04, 2017; revised/accepted: November 14, 2018; available online: February 04, 2019. 


\begin{tabular}{|c|c|c|c|c|c|c|c|c|c|c|c|c|c|c|c|c|c|c|}
\hline \multirow[b]{2}{*}{$\begin{array}{c}\text { Spot } \\
\text { Name }\end{array}$} & \multirow[b]{2}{*}{$\begin{array}{c}\text { ppm } \\
\text { Total Pb }\end{array}$} & \multirow[b]{2}{*}{$\begin{array}{l}\text { ppm } \\
{ }^{232} \mathrm{Th}\end{array}$} & \multirow[b]{2}{*}{${ }_{238} \mathbf{p p m}$} & \multirow[b]{2}{*}{${ }^{232} \mathbf{T h} /{ }^{238} \mathbf{U}$} & \multirow[b]{2}{*}{${ }^{207} \mathrm{~Pb} /{ }^{206} \mathrm{~Pb}$} & \multirow[b]{2}{*}{$\begin{array}{c}\% \\
\pm 1 \sigma\end{array}$} & \multirow[b]{2}{*}{${ }^{207} \mathbf{P b} /{ }^{235} \mathbf{U}$} & \multirow[b]{2}{*}{$\begin{array}{c}\% \\
\pm 1 \sigma\end{array}$} & \multirow[b]{2}{*}{${ }^{206} \mathrm{~Pb} /{ }^{238} \mathbf{U}$} & \multirow[b]{2}{*}{$\begin{array}{c}\% \\
\pm 1 \sigma\end{array}$} & \multirow[b]{2}{*}{ rho } & \multicolumn{7}{|c|}{ aparent ages } \\
\hline & & & & & & & & & & & & ${ }^{207} \mathrm{~Pb} /{ }^{206} \mathrm{~Pb}$ & $\begin{array}{l}\text { Ma } \\
\pm 1 \sigma\end{array}$ & ${ }^{207} \mathbf{P b} /{ }^{235} \mathbf{U}$ & $\begin{array}{l}\text { Ma } \\
\pm 1 \sigma\end{array}$ & ${ }^{206} \mathbf{P b}{ }^{238} \mathbf{U}$ & $\begin{array}{l}\mathrm{Ma} \\
\pm 1 \sigma\end{array}$ & $\begin{array}{c}\% \\
\text { conc. }\end{array}$ \\
\hline \multicolumn{19}{|c|}{ 76-Orthogneiss } \\
\hline 76-01 & 910,527 & 674,013 & $1.240,292$ & 0,5434 & 0,107 & 0,0024 & 394,053 & 0,1343 & 0,2617 & 0,007 & 0,7352 & $1.742,6$ & 40,74 & $1.622,0$ & 27,6334 & $1.498,6$ & 33,53 & 92 \\
\hline 76-02 & 187,403 & 275,213 & 311,810 & 0,8826 & 0,075 & 0,0023 & 198,534 & 0,0644 & 0,1906 & 0,003 & 0,5191 & $1.076,9$ & 59,73 & $1.110,5$ & 21,9182 & $21.124,6$ & 17,39 & 98 \\
\hline $76-03$ & 513,227 & 422,232 & $1.126,880$ & 0,3747 & 0,092 & 0,0021 & 237,815 & 0,0595 & 0,1848 & 0,002 & 0,3676 & $1.465,1$ & 42,60 & $1.236,1$ & 17,8932 & $1.093,4$ & 9,26 & 87 \\
\hline $76-04$ & $1.361,995$ & $1.526,596$ & $1.184,560$ & 1,2887 & 0,099 & 0,0019 & 360,086 & 0,0877 & 0,2618 & 0,004 & 0,6162 & $1.596,0$ & 35,18 & $1.549,7$ & 19,3929 & $1.499,2$ & 20,10 & 96 \\
\hline $76-05$ & 462,435 & 403,827 & 343,730 & 1,1748 & 0,112 & 0,0026 & 479,779 & 0,1119 & 0,3087 & 0,003 & 0,3963 & $1.831,5$ & 42,28 & $1.784,5$ & 19,6280 & $1.734,3$ & 14,08 & 97 \\
\hline $76-06$ & $1.971,711$ & $2.208,277$ & $2.094,787$ & 1,0542 & 0,105 & 0,0020 & 361,755 & 0,0757 & 0,2483 & 0,002 & 0,4618 & $1.707,1$ & 35,19 & $1.553,4$ & 16,6836 & $51.429,5$ & 12,42 & 91 \\
\hline 76-07 & $1.192,769$ & $1.153,387$ & 734,035 & 1,5713 & 0,107 & 0,0023 & 460,993 & 0,1051 & 0,3082 & 0,003 & 0,4537 & $1.766,7$ & 38,58 & $1.751,1$ & 19,0601 & $1.731,9$ & 15,74 & 98 \\
\hline $76-08$ & 361,581 & 422,213 & 396,767 & 1,0641 & 0,092 & 0,0026 & 2,919 & 0,0878 & 0,2291 & 0,003 & 0,4090 & $1.465,7$ & 55,09 & $1.386,8$ & 22,7738 & $1.329,9$ & 14,81 & 95 \\
\hline 76-09 & 504,782 & 492,058 & 373,418 & 1,3177 & 0,103 & 0,0028 & 442,434 & 0,1203 & 0,3085 & 0,003 & 0,3733 & $1.684,9$ & 82,41 & $1.716,9$ & 22,5574 & $1.733,5$ & 15,46 & 99 \\
\hline $76-10$ & 358,078 & 310,146 & 527,135 & 0,5884 & 0,098 & 0,0028 & 347,902 & 0,1247 & 0,2488 & 0,005 & 0,5594 & $1.594,4$ & 56,48 & $1.522,5$ & 28,2931 & $1.432,1$ & 25,77 & 93 \\
\hline $76-11$ & 165,558 & 3,538 & 342,420 & 0,6236 & 0,081 & 0,0026 & 19,348 & 0,0636 & 0,1726 & 0,002 & 0,3164 & 13,9 & 62,96 & $1.093,2$ & 22,0155 & 6,6 & 9,89 & 93 \\
\hline $76-12$ & 361,153 & 1,240 & 209,038 & 1,5846 & 0,114 & 0,0031 & 529,131 & 0,1484 & 0,3351 & 0,004 & 0,4092 & 7 & 48,92 & $1.867,5$ & 23,9840 & $1.863,0$ & 18,60 & 99 \\
\hline $76-13$ & 539,014 & 5,417 & 310,196 & 1,6938 & 0,108 & 0,0028 & 47,766 & 0,1217 & 0,3182 & 0,003 & 0,4092 & $1.773,8$ & 46,30 & $1.780,8$ & 21,4339 & $1.781,1$ & 16,26 & 99 \\
\hline $76-14$ & 401,650 & 376,828 & 351,473 & 1,0721 & 0,105 & 0,0025 & 416,242 & 0,1047 & 0,2868 & 0,003 & 0,4219 & $1.705,9$ & 44,29 & $1.666,7$ & 20,6300 & $1.625,4$ & 15,28 & 97 \\
\hline $76-15$ & 292,950 & 384 & 198,911 & 1,2336 & 0,114 & 0,0031 & 498,241 & 0,1427 & & 0,003 & & & 49,69 & $1.816,3$ & & & 16,55 & 96 \\
\hline $76-16$ & 610,580 & ,466 & 802,751 & 0,68 & 0,092 & 0,0020 & 323,237 & 0,0924 & 0,2504 & 0,004 & 37 & & 41,51 & $1.465,0$ & 22 , & $2.440,6$ & 20,08 & 98 \\
\hline $76-17$ & 341,661 & 206 & 225,588 & 1,3840 & 0,102 & 0,0027 & 465,833 & 0,1178 & 0,3317 & 0,003 & 0,3947 & $1.654,6$ & 48,61 & $1.759,8$ & 21,1805 & & 16,06 & 95 \\
\hline $76-18$ & 179,601 & 318,086 & 320,072 & 0,9938 & 0,094 & 0,0041 & 230,703 & 0,1024 & 0,1761 & 0,002 & 0,2261 & $1.505,6$ & 81,79 & $1.214,5$ & 31,4519 & $1.045,7$ & 9,70 & 85 \\
\hline $76-19$ & & & $1.385,827$ & 0 , & 9 & 0,0024 & 644 & 0,1488 & & 0,007 & & & 50,01 & 1.5 & 32 , & & 33,34 & 97 \\
\hline $76-20$ & 530,812 & 427,923 & 401,932 & 1,0647 & 0,108 & 0,0032 & 462,178 & 0,141 & 0,3058 & 0,003 & 0,3428 & 1.772 & 53,40 & $1.753,2$ & 25,5036 & $61.720,0$ & 15,82 & 98 \\
\hline \multicolumn{19}{|c|}{ 77-Orthogneiss } \\
\hline $77-01$ & 16,262 & 309 & 208 & 0,356 & 0,06669 & 0,00460 & 1,48673 & 0,09045 & 0,16841 & 0,00297 & 0,29014 & 827,78 & 144,44 & 924,98 & 36,94 & $1.003,37$ & 16,41 & 91 \\
\hline $77-02$ & 26,464 & 33,118 & 114,250 & 0,290 & 0,07414 & 0,00405 & 1,78547 & 0,09040 & 0,17968 & 0,00360 & 0,39536 & $1.055,56$ & 110,04 & $1.040,18$ & 32,96 & $1.065,24$ & 19,66 & 97 \\
\hline $77-03$ & 29,495 & 50,861 & 153,756 & 0,331 & 0,06836 & 0,00293 & 1,54270 & 0,06555 & 0,16399 & 0,00234 & 0,33641 & 879,63 & 88,89 & 947,58 & 26,18 & 978,94 & 12,99 & 96 \\
\hline $77-04$ & 29,861 & 37,846 & 119,261 & 0,317 & 0,08920 & 0,00434 & 1,93533 & 0,09133 & 0,15949 & 0,00261 & 0,34730 & $1.409,26$ & 88,43 & $1.093,38$ & 31,60 & 953,91 & 14,54 & 86 \\
\hline $77-05$ & 6025 & 26.056 & 075 & 0244 & 0,08802 & 0,01261 & 2,16878 & 0,37854 & 0,17611 & 0,00337 & 0,10978 & $1.383,34$ & 277,93 & $1.171,09$ & 121,30 & $1.045,70$ & 18,51 & 88 \\
\hline $77-06$ & 34,204 & 57,796 & 175,444 & 0,329 & 0,07357 & 0,00291 & 1,68776 & 0,06635 & 0,16644 & 0,00213 & 0,32530 & $1.029,32$ & 81,02 & $1.003,92$ & 25,07 & 992,46 & 11,77 & 98 \\
\hline $77-07$ & 67,821 & 119,772 & 299,626 & 0,400 & 0,07523 & 0,00243 & 1,79855 & 0,05645 & 0,17267 & 0,00187 & 0,34571 & $1.075,93$ & 64,82 & $1.044,93$ & 20,49 & $1.026,83$ & 10,31 & 98 \\
\hline $77-08$ & 19,116 & 27,397 & 115,782 & 0,237 & 0,07724 & 0,00374 & 1,74724 & 0,08034 & 0,16493 & 0,00242 & 0,31846 & $1.127,79$ & 96,30 & $1.026,14$ & 29,70 & 984,12 & 13,38 & 95 \\
\hline 77-09 & 41310 & 60,113 & 199,333 & 0320 & 0,07827 & 0,00282 & 1,95798 & 0,07102 & 0,18078 & 0,00288 & 0,43872 & $1.153,71$ & 76,39 & $1.101,19$ & 24,39 & $1.071,24$ & 15,72 & 97 \\
\hline $77-10$ & 18,041 & 26.472 & 102,312 & 0,259 & 0,07950 & 0,00458 & 1,77767 & 0,09019 & 0,16630 & 0,00297 & 0,35177 & $1.184,88$ & 114,04 & $1.037,33$ & 32,98 & 991,67 & 16,41 & 95 \\
\hline $77-11$ & 32,776 & 51,446 & 122,751 & 0,419 & 0,08161 & 0,00455 & 1,79362 & 0,09463 & 0,16121 & 0,00247 & 0,29028 & $1.236,11$ & 109,26 & $1.043,14$ & 34,40 & 963,49 & 13,72 & 92 \\
\hline $77-12$ & 20,330 & 24,706 & 105,468 & 0,234 & 0,06772 & 0,00373 & 1,49397 & 0,08035 & 0,16138 & 0,00273 & 0,31404 & 861,11 & 114,81 & 927,93 & 32,72 & 964,46 & 15,14 & 96 \\
\hline $77-13$ & 143,164 & 244,859 & 578,835 & 0,423 & 0,07858 & 0,00208 & 2,05861 & 0,05589 & 0,18815 & 0,00206 & 0,40273 & $1.161,12$ & 51,85 & $1.135,16$ & 18,57 & $1.111,35$ & 11,18 & 97 \\
\hline $77-14$ & 439,345 & 987,737 & $1.397,136$ & 0,707 & 0,07528 & 0,00159 & 1,79147 & 0,03650 & 0,17082 & 0,00125 & 0,35973 & $1.075,93$ & 42,28 & $1.042,36$ & 13,30 & $1.016,64$ & 6,92 & 97 \\
\hline $77-15$ & 196,700 & 275,275 & $1.013,765$ & 0,272 & 0,07736 & 0,00163 & 1,94908 & 0,04089 & 0,18079 & 0,00145 & 0,38168 & $1.131,49$ & 42,13 & $1.098,13$ & 14,10 & $1.071,31$ & 7,92 & 97 \\
\hline $77-16$ & 226,286 & 487,742 & 745,705 & 0,654 & 0,07701 & 0,00183 & 1,85743 & 0,04392 & 0,17335 & 0,00151 & 0,36824 & $1.121,30$ & 47,68 & $1.066,07$ & 15,62 & $1.030,53$ & 8,31 & 96 \\
\hline $77-17$ & 161,901 & 305,235 & 609,069 & 0,501 & 0,07623 & 0,00183 & 1,91952 & 0,04674 & 0,18068 & 0,00159 & 0,36144 & $1.101,85$ & 48,15 & $1.087,90$ & 16,27 & $1.070,71$ & 8,70 & 98 \\
\hline $77-18$ & 130,801 & 222,738 & 300,743 & 0,741 & 0,09085 & 0,00261 & 2,55786 & 0,07799 & 0,20162 & 0,00227 & 0,36876 & $1.443,52$ & 55,40 & $1.288,68$ & 22,27 & $1.184,01$ & 12,18 & 91 \\
\hline $77-19$ & 271,708 & 64 & & & & & & & & 0,00169 & 0,39381 & & 56,48 & $1.024,42$ & 16,34 & $1.008,69$ & 9,32 & 98 \\
\hline $77-20$ & 47,424 & 80,901 & 216,018 & 0,375 & 0,07454 & 0,00309 & 1,72452 & 0,07108 & 0,16773 & 0,00209 & 0,30185 & $1.057,41$ & 84,42 & $1.017,71$ & 26,50 & 999,59 & 11,53 & 98 \\
\hline
\end{tabular}




\begin{tabular}{|c|c|c|c|c|c|c|c|c|c|c|c|c|c|c|c|c|c|c|}
\hline \multirow[b]{2}{*}{$\begin{array}{c}\text { Spot } \\
\text { Name }\end{array}$} & \multirow[b]{2}{*}{$\begin{array}{c}\text { ppm } \\
\text { Total Pb }\end{array}$} & \multirow[b]{2}{*}{$\underset{\text { ppm }}{{ }^{232} \mathrm{Th}}$} & \multirow[b]{2}{*}{${ }^{p 238} \mathrm{U}$} & \multirow[b]{2}{*}{${ }^{232} \mathbf{T h} /{ }^{238} \mathbf{U}$} & \multirow[b]{2}{*}{${ }^{207} \mathrm{~Pb} /{ }^{206} \mathrm{~Pb}$} & \multirow[b]{2}{*}{$\begin{array}{c}\% \\
\pm 1 \sigma\end{array}$} & \multirow[b]{2}{*}{${ }^{207} \mathbf{P b} \mathbf{b}^{235} \mathbf{U}$} & \multirow[b]{2}{*}{$\begin{array}{c}\% \\
\pm 1 \sigma\end{array}$} & \multirow[b]{2}{*}{${ }^{206} \mathbf{P b} \mathbf{b} /{ }^{238} \mathbf{U}$} & \multirow[b]{2}{*}{$\begin{array}{c}\% \\
\pm 1 \sigma\end{array}$} & \multirow[b]{2}{*}{ rho } & \multicolumn{7}{|c|}{ aparent ages } \\
\hline & & & & & & & & & & & & $\mathbf{P b} /{ }^{206} \mathbf{P b}$ & $\begin{array}{l}\mathrm{Ma} \\
\pm 1 \sigma\end{array}$ & $\mathrm{U}$ & $\begin{array}{l}\mathrm{Ma} \\
\pm 1 \sigma\end{array}$ & ${ }^{206}$ & $\begin{array}{l}\mathrm{Ma} \\
\pm 1 \sigma\end{array}$ & $\begin{array}{c}\% \\
\text { conc. }\end{array}$ \\
\hline \multicolumn{19}{|c|}{ 75-Quartz diorite } \\
\hline $75-01$ & 107,577 & $1.575,893$ & 751,811 & 2,09613 & 0,051838 & 0,00289 & 0,22479 & 0,012 & 0,031398 & 0,0004 & 0,25809 & 279,69 & 160,17 & 205,89 & 9,929 & 199,29 & 2,70 & 96 \\
\hline $75-02$ & 178,816 & $2.733,879$ & $1.039,186$ & 2,63079 & 0,051601 & 0,00237 & 0,22370 & 0,0101 & 0,031291 & 0,0004 & 0,27083 & 333,39 & 100,91 & 204,98 & 8,345 & 198,62 & 2,38 & 96 \\
\hline $75-03$ & 614,932 & 819,034 & 607,193 & 1,34888 & 0,05246 & 0,00307 & 0,22844 & 0,0132 & 0,031331 & 0,0004 & 0,23171 & 305,62 & 135,17 & 208,91 & 10,935 & 198,87 & 2,63 & 95 \\
\hline 75-04 & 346,234 & $5.653,242$ & $1.915,336$ & 2,95157 & 0,05035 & 0,00183 & 0,21741 & 0,0077 & 0,031038 & 0,0003 & 0,29158 & 209,33 & 87,95 & 199,75 & 6,437 & 197,04 & 2,01 & 98 \\
\hline $75-05$ & 141,475 & $1.995,540$ & 977,685 & 2,04109 & 0,050382 & 0,00279 & 0,21998 & 0,0109 & 0,032097 & 0,0004 & 0,25703 & 213,04 & 132,39 & 201,89 & 9,058 & 203,66 & 2,55 & 99 \\
\hline $75-06$ & 901,069 & $1.338,714$ & 715,126 & 1,87200 & 0,046143 & 0,00241 & 0,20249 & 0,0107 & 0,031702 & 0,0005 & 0,26811 & 400,05 & 272,19 & 187,23 & 9,058 & 201,19 & 2,82 & 92 \\
\hline $75-07$ & 107,547 & $1.605,213$ & 777,782 & 2,06383 & 0,047332 & 0,00245 & 0,20519 & 0,0107 & 0,031153 & 0,0004 & 0,26301 & 64,91 & 118,51 & 189,51 & 9,024 & 197,76 & 2,68 & 95 \\
\hline $75-08$ & 169,928 & $2.440,495$ & $1.132,164$ & 2,15560 & 0,063251 & 0,00363 & 0,28266 & 0,0175 & 0,031532 & 0,0004 & 0,19584 & 716,68 & 122,21 & 252,76 & 13,860 & 200,13 & 2,39 & 76 \\
\hline $75-09$ & 103,164 & $1.441,664$ & 863,503 & 1,66955 & 0,050425 & 0,00302 & 0,21540 & 0,0116 & 0,031376 & 0,0004 & 0,24994 & 213,04 & 134,24 & 198,08 & 9,65 & 199,15 & 2,63 & 99 \\
\hline $75-10$ & 101,861 & $1.398,328$ & 857,089 & 1,63148 & 0,04578 & 0,00252 & 0,19982 & 0,0103 & 0,031953 & 0,0004 & 0,25092 & error & - & 184,97 & 8,72 & 202,76 & 2,59 & 90 \\
\hline $75-11$ & 114,818 & $1.677,404$ & 881,666 & 1,90254 & 0,049009 & 0,00271 & 0,21257 & 0,0116 & 0,031342 & 0,0004 & 0,26171 & 150,09 & 129,61 & 195,71 & 9,68 & 198,94 & 2,79 & 98 \\
\hline $75-12$ & 399,111 & 584,466 & 618,568 & 0,94487 & 0,097764 & 0,00220 & 3,68205 & 0,0846 & 0,270937 & 0,0027 & 0,43270 & $1.583,34$ & 47,06 & 1567,48 & 18,39 & $1.545,56$ & 13,69 & 98 \\
\hline $75-13$ & 129,407 & $1.822,340$ & 927,364 & 1,96508 & 0,05244 & 0,00266 & 0,23179 & 0,012 & 0,031955 & 0,0004 & 0,25355 & 305,62 & 116,65 & 211,67 & 9,87 & 202,77 & 2,62 & 95 \\
\hline $75-14$ & 131,225 & $1.954,248$ & 995,423 & 1,96323 & 0,047387 & 0,00225 & 0,19697 & 0,0091 & 0,030083 & 0,0004 & 0,26331 & 77,87 & 111,10 & 182,56 & 7,69 & 191,07 & 2,28 & 95 \\
\hline $75-15$ & 218,127 & $3.157,272$ & $1.247,168$ & 2,53155 & 0,05069 & 0,00249 & 0,22048 & 0,011 & 0,031336 & 0,0004 & 0,24530 & 233,40 & 117,58 & 202,31 & 9,17 & 198,90 & 2,40 & 98 \\
\hline $75-16$ & 228,789 & $3.265,911$ & $1.354,018$ & 2,41201 & 0,050981 & 0,00216 & 0,21501 & 0,0087 & 0,030736 & 0,0003 & 0,28068 & 238,96 & 102,76 & 197,74 & 7,24 & 195,15 & 2,17 & 98 \\
\hline $75-17$ & 100,084 & $1.412,564$ & $1.002,914$ & 1,40846 & 0,051042 & 0,00268 & 0,21623 & 0,0106 & 0,031292 & 0,0004 & 0,27423 & 242,66 & 124,98 & 198,76 & 8,82 & 198,63 & 2,62 & 99 \\
\hline $75-18$ & 117,686 & $1.609,962$ & 918,583 & 1,75266 & 0,047628 & 0,00290 & & 0,0118 & 0,03 & 0,0004 & 0,24411 & 79,72 & 140,72 & 188,81 & 9,95 & 200,36 & 2,78 & 94 \\
\hline $75-19$ & 100,374 & $1.408,096$ & 873,896 & 16,1129 & 0,051187 & 0,00276 & 0,21 & 0,0116 & 0,030 & 0,0004 & 0,23669 & 250,07 & 124,06 & 196,02 & 9,69 & 191,52 & 2,43 & 97 \\
\hline $75-20$ & 153,166 & $2.293,409$ & 981,574 & 2,33646 & 0,048431 & 0,00288 & 0,20143 & 0,0113 & 0,030501 & 0,0004 & 0,24700 & 120,46 & 133,31 & 186,33 & 9,51 & 193,68 & 2,64 & 96 \\
\hline \multicolumn{19}{|c|}{ 82-Diorite } \\
\hline $82-01$ & 315,593 & $3.502,748$ & $2.019,393$ & 1,734556 & 0,064646 & 0,0028 & 0,289958 & 0,0139 & 0,03176 & 0,0004 & 0,242711 & 762,66 & 60,18 & 258,53 & 10,95 & 201,55 & 2,31 & 75 \\
\hline $82-02$ & 100,232 & $1.353,733$ & 725,055 & 1,867077 & 0,052727 & 0,0027 & 0,220743 & 0,0112 & 0,030338 & 0,0004 & 0,290473 & 316,73 & 116,65 & 202,53 & 9,33 & 192,66 & 2,80 & 95 \\
\hline $82-03$ & 164,242 & $1.923,429$ & $1.280,511$ & 1,50208 & 0,051337 & 0,0022 & 276 & 0,0092 & 0,031273 & 0,0004 & 0,2 & 257,47 & 98,13 & 202,97 & 7,64 & 198,51 & 2,21 & 97 \\
\hline 82-04 & 52,279 & 427,185 & 286,607 & 1,490492 & 0,052955 & 0,005 & 0,207311 & 0,0174 & 0,030423 & 0,0006 & 0,233275 & 327,84 & 214,79 & 191,29 & 14,60 & 193,20 & 3,72 & 99 \\
\hline $82-05$ & 97,414 & $1.167,361$ & 709,428 & 1,64547 & 0,056562 & 0,0031 & 0,24161 & 0,0127 & 0,031506 & 0,0004 & 0,24073 & 475,97 & 122,21 & 219,74 & 10,37 & 199,97 & 2,49 & 90 \\
\hline $82-06$ & 56,546 & 559,578 & 451,402 & 1,23965 & 0,06117 & 0,0041 & 0,257706 & 0,0168 & 0,031253 & 0,0005 & 0,262657 & 655,57 & 141,65 & 232,82 & 13,59 & 198,39 & 3,35 & 84 \\
\hline $82-07$ & $12.101,305$ & 0 & 0 & 0 & 0,02367 & 0,0038 & 0,126207 & 0,0118 & 0,024592 & 0,0003 & 0,12813 & error & error & 120,68 & 10,65 & 156,62 & 1,86 & 74 \\
\hline $82-08$ & 136,910 & $1.308,169$ & 804,029 & 1,627018 & 0,080467 & 0,0046 & 0,39178 & 0,0255 & 0,033376 & 0,0005 & 0,228944 & $1.209,26$ & 112,19 & 335,67 & 18,61 & 211,64 & 3,11 & 54 \\
\hline $82-09$ & 162,167 & $1.932,777$ & $1.251,114$ & 1,544845 & 0,056303 & 0,0027 & 0,237922 & 0,0117 & 0,03086 & 0,0004 & 0,244994 & 464,86 & 107,40 & 216,72 & 9,56 & 195,93 & 2,32 & 89 \\
\hline $82-10$ & 63,008 & 662,568 & 644,777 & 1,027593 & 0,051431 & 0,0028 & 0,221154 & 0,0118 & 0,031562 & 0,0005 & 0,292068 & 261,18 & 128,69 & 202,87 & 9,78 & 200,32 & 3,07 & 98 \\
\hline $82-11$ & 206,608 & $2.631,565$ & $1.507,509$ & 1,745638 & 0,049024 & 0,0019 & 0,206804 & 0,0081 & 0,030726 & 0,0004 & 0,308439 & 150,09 & 92,58 & 190,87 & 6,85 & 195,09 & 2,33 & 97 \\
\hline $82-12$ & 411,863 & $3.581,831$ & $2.263,384$ & 1,582512 & 0,084642 & 0,0053 & 0,408924 & 0,0304 & 0,032623 & 0,0004 & 0,160916 & $1.307,10$ & 118,05 & 348,10 & 21,94 & 206,95 & 2,44 & 49 \\
\hline $82-13$ & 769,774 & $10.407,978$ & $5.152,240$ & 2,020088 & 0,125234 & 0,0149 & 1,306083 & 0,2796 & 0,05148 & 0,0055 & 0,495648 & $2.032,41$ & 211,57 & 848,40 & 123,13 & 323,60 & 33,49 & 10 \\
\hline $82-14$ & 702,496 & $9.943,927$ & $4.778,629$ & 2,080916 & 0,049608 & 0,0012 & 0,207626 & 0,0054 & 0,030188 & 0,0003 & 0,348421 & 176,01 & 59,25 & 191,56 & 4,55 & 191,72 & 1,72 & 99 \\
\hline $82-15$ & 276,830 & $3.940,983$ & $1.865,787$ & 2,112236 & 0,062943 & 0,0028 & 0,259917 & 0,0118 & 0,029744 & 0,0003 & 0,238867 & 705,57 & 94,44 & 234,60 & 9,54 & 188,95 & 2,03 & 78 \\
\hline $82-16$ & 293,990 & $3.865,224$ & $1.947,415$ & 1,984797 & 0,050754 & 0,0019 & 0,215894 & 0,0081 & 0,030933 & 0,0003 & 0,301091 & 227,85 & 91,65 & 198,49 & 6,76 & 196,38 & 2,19 & 98 \\
\hline $82-17$ & 100,663 & $1.014,216$ & 601,693 & 1,685606 & 0,054395 & 0,0032 & 0,22667 & 0,0126 & 0,030827 & 0,0004 & 0,255305 & 387,09 & 136,10 & 207,45 & 10,40 & 195,72 & 2,73 & 94 \\
\hline $82-18$ & 33,643 & 193,218 & 185,538 & 1,041391 & 0,082254 & 0,0064 & 0,339812 & 0,025 & 0,030415 & 0,0006 & 0,266885 & $1.251,54$ & 149,08 & 297,03 & 18,91 & 193,15 & 3,73 & 57 \\
\hline $82-19$ & 87,433 & $1.009,726$ & 723,820 & 1,394996 & 0,050669 & 0,0035 & 0,205748 & 0,0126 & 0,030503 & 0,0004 & 0,228674 & 233,40 & 157,39 & 189,98 & 10,64 & 193,69 & 2,68 & 98 \\
\hline $82-20$ & 174,323 & $2.159,582$ & $1.219,644$ & 1,770666 & 0,048945 & 0,002 & 0,210236 & 0,0087 & 0,031089 & 0,0004 & 0,284622 & 146,38 & 98,13 & 193,75 & 7,31 & 197,36 & 2,30 & 98 \\
\hline
\end{tabular}




\begin{tabular}{|c|c|c|c|c|c|c|c|c|c|c|c|c|c|c|c|c|c|c|}
\hline \multirow[b]{2}{*}{$\begin{array}{c}\text { Spot } \\
\text { Name }\end{array}$} & \multirow[b]{2}{*}{$\begin{array}{c}\text { ppm } \\
\text { Total Pb } \\
\end{array}$} & \multirow[b]{2}{*}{$\begin{array}{c}\text { ppm } \\
{ }^{232} \mathrm{Th} \\
\end{array}$} & \multirow[b]{2}{*}{${ }_{{ }^{238} \mathbf{U}}^{\mathbf{p p m}}$} & \multirow[b]{2}{*}{${ }^{232} \mathbf{T h} /{ }^{238} \mathbf{U}$} & \multirow[b]{2}{*}{${ }^{207} \mathrm{~Pb} /{ }^{206} \mathrm{~Pb}$} & \multirow[b]{2}{*}{$\begin{array}{c}\% \\
\pm 1 \sigma \\
\end{array}$} & \multirow[b]{2}{*}{${ }^{207} \mathbf{P b} /{ }^{235} \mathbf{U}$} & \multirow[b]{2}{*}{$\begin{array}{c}\% \\
\pm 1 \sigma\end{array}$} & \multirow[b]{2}{*}{${ }^{206} \mathbf{P b} /{ }^{238} \mathbf{U}$} & \multirow[b]{2}{*}{$\begin{array}{r}\% \\
\pm 1 \sigma\end{array}$} & \multirow[b]{2}{*}{ rho } & \multicolumn{7}{|c|}{ aparent ages } \\
\hline & & & & & & & & & & & & b & $\begin{array}{l}\text { Ma } \\
\pm 1 \sigma\end{array}$ & $\mathbf{U}$ & $\begin{array}{l}\text { Ma } \\
\pm 1 \sigma\end{array}$ & U & $\begin{array}{l}\text { Ma } \\
\pm 1 \sigma\end{array}$ & $\begin{array}{c}\% \\
\text { conc. }\end{array}$ \\
\hline \multicolumn{19}{|c|}{ 89-Tonalite } \\
\hline 89-01 & 0,00585 & 05717 & 0,05910 & 0,96740 & ,064026 & 0,0024 & 257321 & 0,0101 & 028581 & 0,0003 & 0,294342 & 742,60 & 79,62 & 232,51 & 8,14 & 181,66 & 2,07 & 75 \\
\hline $89-02$ & 0,01885 & 17075 & 0,21447 & 0,79614 & 0,058449 & 0,0024 & 0,23456 & 0,0099 & 0,028817 & 0,0003 & 0,266886 & 546,33 & 90,73 & 213,96 & 8,11 & 183,14 & 2,03 & 84 \\
\hline $89-03$ & 0,01789 & 0,17751 & 0,20730 & 0,85628 & 0,04837 & 0,0021 & 0,191169 & 0,0082 & 0,028267 & 0,0003 & 0,239217 & 116,76 & 101,84 & 177,63 & 7,01 & 179,69 & 1,83 & 98 \\
\hline 89-04 & 0,03025 & 0,29166 & 0,33415 & 0,87285 & 0,047375 & 0,0018 & 0,18909 & 0,007 & 0,028743 & 0,0003 & 0,280982 & 77,87 & 75,92 & 175,85 & 5,97 & 182,68 & 1,87 & 96 \\
\hline $89-05$ & 0,00095 & 0809 & 0,00609 & 1,32723 & 0,082534 & 0,0029 & $0,3 / 14$ & 0148 & 031445 & 0,0004 & 0,303699 & $1.258,33$ & 70,37 & 321,12 & 10,96 & 199,59 & 2,38 & 53 \\
\hline $89-06$ & 0,02693 & 0,24043 & 0,28168 & 0,85356 & 0,048764 & 0,0018 & 0,199264 & 0,0072 & 0,029485 & 0,0003 & 0,308854 & 200,08 & 82,40 & 184,50 & 6,09 & 187,32 & 2,06 & 98 \\
\hline $89-07$ & 0,00053 & 0,00482 & 0,00250 & 1,92618 & 0,133258 & 0,006 & 0,519735 & 0,023 & 0,0280019 & 0,0003 & 0,208619 & $2.142,59$ & 78,55 & & 15,34 & & 1,62 & 18 \\
\hline $89-08$ & 0,02373 & 0,20774 & 0,27754 & 0,74853 & 0,054175 & 0,0025 & 0,217803 & 0,0098 & 0,029186 & 0,0004 & 0,282982 & 388,94 & 101,84 & 200,08 & 8,13 & 185,45 & 2,32 & 92 \\
\hline 89-09 & 0,00383 & 3853 & 0,02986 & 1,29050 & 0,051 & 0,002 & $0,20 \varnothing$ & 0,0079 & 72 & 0,0003 & 292906 & 261,18 & 88,88 & & 6,62 & & 2,02 & 96 \\
\hline $89-10$ & 0568 & 37163 & 14,800 & 1,19480 & 0,047968 & 0,0021 & 0.186117 & 0,0079 & 0,028183 & 0,0003 & 0,288522 & 98,24 & 99,99 & 173,31 & 6,78 & 179,17 & 2,17 & 96 \\
\hline $89-11$ & 0 & 1186 & 0,26031 & 1,19806 & 0 , & 0,0018 & 9 & 0,0068 & & 0,0003 & 56 & 235 & 83,32 & & 5,80 & & 1,84 & 97 \\
\hline $89-12$ & 0,39971 & 3,78655 & 457,717 & 0,82727 & 0,051202 & 0,0021 & 0,20334 & 0,0083 & 0,028715 & 0,0003 & 0,272632 & 250,07 & 94,43 & 187,95 & 7,01 & 182,50 & 2,01 & 97 \\
\hline $89-13$ & 0 , & & & & & 0 & & & & 0,0004 & & & 65,73 & & & & 2,41 & 98 \\
\hline 89-14 & & & & & 0 , & 0,0027 & & 07 & & 0,0003 & 64 & & 94,59 & & 8,67 & & 1,90 & 76 \\
\hline $89-15$ & 0 , & 15 & 21 & 1,12 & 0,05 & 0,0022 & 0,20 & 0,0 & 0,02 & 0,0003 & 0,28766 & 2 & 92,58 & 18 & 6,88 & & 2,03 & 94 \\
\hline $89-16$ & 0,01437 & 0,13828 & 0,14343 & 0,96409 & 0,049715 & 0,0017 & 0,199844 & 0,0066 & 0,028928 & 0,0003 & 0,343247 &, 97 & 77,77 & 184,99 & 5,59 & 183,83 & 2,06 & 99 \\
\hline $89-17$ & & & & & & 0 & & & & 0,0004 & & & & & & & 2,52 & 88 \\
\hline $89-18$ & 3494 & & & 35 & 0,0 & 0,002 & & 0,0081 & & 0,0003 & 0,2 & 1 & 98,14 & & 6,91 & & 2,04 & 99 \\
\hline $89-19$ & 0,09244 & 4 & 4 & 1,14565 & 0,048 & 0,0016 & 26 & 0,0064 & 0,029779 & 0,0003 & 0,322501 & 1 & 77,77 & & 5,42 & & 1,95 & 96 \\
\hline $89-20$ & 0,01784 & 0,16733 & 20156 & 0,83019 & 0,050947 & 0,0019 & 0,201442 & 0,0073 & 0,028731 & 0,0003 & 0,303097 & 238,96 & 83,32 & 186,35 & 6,14 & 182,60 & 1,97 & 97 \\
\hline \multicolumn{19}{|c|}{ 95A-Granodiorite } \\
\hline $95 \mathrm{~A}-01$ & 93,717914 & 03,95 & 60 & 0,627497 & 58 & 0,0019 & 76 & 0074 & 03 & 0,0003 & 62 & 76 & 86,10 & 178,40 & 6,30 & 182 & 1,98 & 97 \\
\hline $95 \mathrm{~A}-02$ & 133,48731 & 815,601 & 687,850 & 0,483219 & 0,051104 & 0,0019 & 0,204183 & 0,0076 & 0,028809 & 0,0003 & 0,291052 & 255,62 & 80,54 & 188,66 & 6,43 & 183,09 & 1,96 & 97 \\
\hline $95 \mathrm{~A}-03$ & 5 & & 1,863 & & 0,0 & 4 & & 91 & & 0,0003 & & 279,69 & 105,54 & & 7,73 & & 2,04 & 55 \\
\hline $95 \mathrm{~A}-04$ & 104,95082 & 773,469 & 28,749 & 0,685245 & 0,07026 & 0,0033 & 0,29 & 0,0155 & 0,029987 & 0,0004 & 0,265762 & $1.000,00$ & 98,15 & 265,92 & 12,09 & 190,47 & 2,58 & 66 \\
\hline $95 \mathrm{~A}-05$ & 138,82252 & $1.906,61$ & $2.344,163$ & 0,813344 & 0,050341 & 0,0016 & 0,20375 & 0,0065 & 0,02904 & 0,0003 & 0,292338 & 209,33 & 41,66 & 188,29 & 5,51 & 184,54 & 1,71 & 97 \\
\hline $95 \mathrm{~A}-06$ & 62,132197 & 420,288 & 810,054 & 0,51884 & 0,051761 & 0,0027 & 0,203629 & 0,0101 & 0,028695 & 0,0004 & 0,270871 & 275,99 & 116,65 & 188,19 & 8,54 & 182,38 & 2,42 & 96 \\
\hline $95 \mathrm{~A}-07$ & 103,88917 & 4355 & 3,256 & 0,654351 & 0,051103 & 00019 & & 0.0077 & 0,029203 & 0,0003 & 0,278484 & 255,62 & 80,54 & 191,29 & 644 & 185,56 & 1,88 & 96 \\
\hline $95 \mathrm{~A}-08$ & 74,71 & 9 & 700 & 0,680251 & 0,052 & 0,0023 & 0.2 & 0,0089 & 0,0 & 0,0003 & 0,25 & 287,10 & 101,84 & 18 & 7,55 & 179,69 & 1,98 & 95 \\
\hline $95 \mathrm{~A}-09$ & 62,657586 & 799,976 & $1.243,635$ & 0,643257 & 0,050449 & 0,0022 & 0,196058 & 0,0084 & 0,027936 & 0,0003 & 0,266096 & 216,74 & 99,99 & 181,79 & 7,10 & 177,62 & 1,99 & 97 \\
\hline $95 \mathrm{~A}-10$ & 43,445886 & 460,593 & 974,976 & 0,472415 & 0,050473 & 0,0024 & 0,194793 & 0,0088 & 0,028087 & 0,0004 & 0,288241 & 216,74 & 107,39 & 180,71 & 7,47 & 178,56 & 2,29 & 98 \\
\hline $95 \mathrm{~A}-11$ & 71,368156 & 021378 & $.505,556$ & 0,611985 & 0,051173 & 0,0022 & & 0,0088 & & 0,0003 & 0,274194 & 255,62 & 98,14 & & 7,41 & 181,50 & 2,12 & 96 \\
\hline $95 \mathrm{~A}-12$ & 45,480236 & 64,850 & 0,350 & 0,546658 & 0,051965 & 0,0028 & 0,214943 & 00115 & 0,029634 & 0,0004 & 0,248728 & 283,40 & 149,98 & 197,69 & 9,63 & 188,26 & 2,48 & 95 \\
\hline $95 \mathrm{~A}-13$ & 35,830509 & 294,717 & 351,010 & 0,839627 & 0,07755 & 0,0056 & 0,299424 & & 0,028817 & 0,0005 & 0,272035 & $1.144,45$ & 142,59 & 265,95 & 14,92 & 183,14 & 3,13 & 63 \\
\hline $95 \mathrm{~A}-14$ & 80,435263 & $1.117,75$ & $1.571,173$ & 0,711411 & 0,051232 & 0,002 & 0,208643 & 0,0082 & 0,029219 & 0,0003 & 0,258376 & 250,07 & 86,10 & 192,41 & 6,92 & 185,66 & 1,87 & 96 \\
\hline $95 \mathrm{~A}-15$ & 44,84881 & 343,036 & 594,268 & 0,577241 & 0,054051 & 0,0033 & 0,21016 & 0,0123 & 0,028422 & 0,0004 & 0,240295 & 372,28 & 137,02 & 193,69 & 10,28 & 180,67 & 2,50 & 93 \\
\hline $95 \mathrm{~A}-16$ & 72,904234 & 939,232 & $1.451,802$ & 0,646942 & 0,047614 & 0,0018 & 0,196189 & 0,0077 & 0,029454 & 0,0003 & 0,267488 & 79,72 & 88,88 & 181,90 & 6,50 & 187,13 & 1,93 & 97 \\
\hline $95 \mathrm{~A}-17$ & 66,194238 & 911,009 & 74,082 & 0,715031 & 0,047348 & & 00520 & & & 0,0003 & 0,24956 & 77,87 & 90,73 & 175,20 & 6,72 & 182,08 & 1,87 & 96 \\
\hline $95 \mathrm{~A}-18$ & 75,985769 & 795,175 & $1.265,643$ & 0,628277 & 0,048656 & 0,0023 & 0,191944 & 0,0085 & 0,028601 & 0,0003 & 0,26082 & 131,57 & 111,10 & 178,29 & 7,28 & 181,79 & 2,08 & 98 \\
\hline $95 \mathrm{~A}-19$ & 84,293857 & 684,325 & $1.221,106$ & 0,560414 & 0,057191 & 0,0026 & 0,239551 & 0,0118 & 0,029636 & 0,0004 & 0,270153 & 498,19 & 101,84 & 218,05 & 9,64 & 188,27 & 2,47 & 85 \\
\hline $95 \mathrm{~A}-20$ & 93,894539 & $1,224,033$ & $1.795,427$ & 0,68175 & 0,049306 & 0,0019 & 0,197942 & 0,0075 & 0,028849 & 0,0003 & 0,301679 & 161,20 & 86,10 & 183,38 & 6,39 & 183,34 & 2,08 & 99 \\
\hline
\end{tabular}




\begin{tabular}{|c|c|c|c|c|c|c|c|c|c|c|c|c|c|c|c|c|c|c|}
\hline \multirow[b]{2}{*}{$\begin{array}{c}\text { Spot } \\
\text { Name }\end{array}$} & \multirow[b]{2}{*}{$\begin{array}{c}\text { ppm Total } \\
\text { Pb }\end{array}$} & \multirow[b]{2}{*}{$\begin{array}{l}\text { ppm } \\
{ }^{232} \mathrm{Th}\end{array}$} & \multirow[b]{2}{*}{${ }_{238}^{\text {ppm }}$} & \multirow[b]{2}{*}{${ }^{232} \mathbf{T h} /{ }^{238} \mathbf{U}$} & \multirow[b]{2}{*}{${ }^{207} \mathrm{~Pb} /{ }^{206} \mathrm{~Pb}$} & \multirow[b]{2}{*}{$\begin{array}{c}\% \\
\pm 1 \sigma\end{array}$} & \multirow[b]{2}{*}{${ }^{207} \mathbf{P b} /{ }^{235} \mathbf{U}$} & \multirow[b]{2}{*}{$\begin{array}{c}\% \\
\pm 1 \sigma\end{array}$} & \multirow[b]{2}{*}{${ }^{206} \mathbf{P b} /{ }^{238} \mathbf{U}$} & \multirow[b]{2}{*}{$\begin{array}{c}\% \\
\pm 1 \sigma\end{array}$} & \multirow[b]{2}{*}{ rho } & \multicolumn{7}{|c|}{ aparent ages } \\
\hline & & & & & & & & & & & & ${ }^{207} \mathbf{P b} /{ }^{206} \mathbf{P b}$ & $\begin{array}{l}\mathrm{Ma} \\
\pm 1 \sigma\end{array}$ & ${ }^{207} \mathrm{~Pb} /{ }^{235} \mathbf{U}$ & $\begin{array}{l}\text { Ma } \\
\pm 1 \sigma\end{array}$ & ${ }^{206} \mathrm{~Pb} \mathbf{b}^{/ 238} \mathbf{U}$ & $\begin{array}{l}\text { Ma } \\
\pm 1 \sigma\end{array}$ & $\begin{array}{c}\% \\
\text { conc. }\end{array}$ \\
\hline \multicolumn{19}{|c|}{ 86-Tonalite } \\
\hline $86-01$ & 33,442794 & 547,138 & 715,623 & 0,764562 & 0,054247 & 0,0034 & 0,170415 & 0,0103 & 0,022729 & 0,0004 & 0,265425 & 388,94 & 140,73 & 159,78 & 8,98 & 144,88 & 2,31 & 90 \\
\hline $86-02$ & 49,974472 & 570,416 & 936,838 & 0,608874 & 0,069042 & 0,0038 & 0,21863 & 0,0113 & 0,023245 & 0,0004 & 0,299215 & 899,69 & 112,96 & 200,77 & 9,42 & 148,13 & 2,27 & 69 \\
\hline $86-03$ & 46,67413 & 755,383 & $1.000,319$ & 0,755142 & 0,049247 & 0,0031 & 0,150367 & 0,0089 & 0,022674 & 0,0003 & 0,250824 & 166,75 & $-49,07$ & 142,24 & 7,89 & 144,53 & 2,13 & 98 \\
\hline $86-04$ & 40,605717 & 693,464 & 872,080 & 0,795183 & 0,045649 & 0,0027 & 0,140266 & 0,0082 & 0,022322 & 0,0003 & 0,260507 & error & - & 133,28 & 7,35 & 142,31 & 2,16 & 93 \\
\hline $86-05$ & 47,780121 & 823,684 & 874,589 & 0,941795 & 0,049889 & 0,003 & 0,157871 & 0,0096 & 0,022998 & 0,0004 & 0,259202 & 190,82 & 140,72 & 148,84 & 8,46 & 146,58 & 2,30 & 98 \\
\hline $86-06$ & 40,787282 & 664,177 & 715,219 & 0,928634 & 0,051682 & 0,0036 & 0,159945 & 0,0106 & 0,023049 & 0,0004 & 0,249145 & 272,29 & 165,72 & 150,66 & 9,24 & 146,90 & 2,39 & 97 \\
\hline $86-07$ & 165,66397 & $3.251,463$ & $2.481,275$ & 1,3104 & 0,047063 & 0,0019 & 0,146381 & 0,0059 & 0,022567 & 0,0003 & 0,304072 & 53,80 & 92,58 & 138,71 & 5,20 & 143,86 & 1,73 & 96 \\
\hline $86-08$ & 55,771748 & 476,215 & 780,246 & 0,610339 & 0,142181 & 0,0105 & 0,527299 & 0,0404 & 0,025492 & 0,0005 & 0,25459 & $2.254,02$ & 128,09 & 430,02 & 26,85 & 162,27 & 3,13 & 9 \\
\hline 86-09 & 31,052135 & 522,184 & 682,894 & 0,764662 & 0,048516 & 0,0035 & 0,152075 & 0,0101 & 0,023393 & 0,0004 & 0,262856 & 124,16 & 162,94 & 143,74 & 8,90 & 149,06 & 2,57 & 96 \\
\hline $86-10$ & 34,586664 & 575,063 & 737,729 & 0,779505 & 0,057929 & 0,0039 & 0,174956 & 0,0109 & 0,022224 & 0,0004 & 0,263039 & 527,82 & 180,53 & 163,71 & 9,43 & 141,70 & 2,30 & 85 \\
\hline $86-11$ & 73,928451 & $1.267,142$ & $1.494,589$ & 0,84782 & 0,049808 & 0,0024 & 0,155915 & 0,0075 & 0,022708 & 0,0003 & 0,274823 & 187,12 & 108,32 & 147,12 & 6,63 & 144,75 & 1,90 & 98 \\
\hline $86-12$ & 63,667566 & $1.151,734$ & $1.321,459$ & 0,871562 & 0,046964 & 0,0025 & 0,142221 & 0,0071 & 0,022031 & 0,0003 & 0,272555 & 55,65 & 112,95 & 135,02 & 6,31 & 140,48 & 1,89 & 96 \\
\hline $86-13$ & 23,794698 & 430,034 & 513,328 & 0,837737 & 0,051963 & 0,0046 & 0,154373 & 0,0131 & 0,022844 & 0,0005 & 0,239486 & 283,40 & 197,20 & 145,77 & 11,49 & 145,60 & 2,92 & 99 \\
\hline $86-14$ & 73,907999 & $1.405,140$ & $1.240,589$ & 1,132639 & 0,056652 & 0,0029 & 0,171649 & 0,0086 & 0,022015 & 0,0003 & 0,267462 & 479,67 & 112,95 & 160,85 & 7,41 & 140,38 & 1,85 & 86 \\
\hline $86-15$ & 27,491569 & 448,812 & 606,539 & 0,739956 & 0,051705 & 0,0036 & 0,159995 & 0,0098 & 0,022962 & 0,0004 & 0,251701 & 272,29 & 163,87 & 150,70 & 8,58 & 146,35 & 2,23 & 97 \\
\hline $86-16$ & 64,232673 & 812,610 & $1.304,624$ & 0,622869 & 0,067795 & 0,0035 & 0,2364 & 0,0131 & 0,024794 & 0,0004 & 0,28697 & 861,11 & 109,26 & 215,47 & 10,77 & 157,88 & 2,49 & 69 \\
\hline $86-17$ & 36,558705 & 632,976 & 766,150 & 0,826177 & 0,049245 & 0,0042 & 0,150891 & 0,0114 & 0,023372 & 0,0004 & 0,220829 & 166,75 & 183,31 & 142,70 & 10,10 & 148,93 & 2,47 & 95 \\
\hline $86-18$ & 95,133189 & $1.776,814$ & $1.649,333$ & 1,077293 & 0,043505 & 0,0021 & 0,138415 & 0,0066 & 0,023182 & 0,0003 & 0,252832 & error & error & 131,63 & 5,87 & 147,73 & 1,76 & 88 \\
\hline 86-19 & 163,53927 & $3.203,723$ & $2.035,733$ & 1,573744 & 0,051338 & 0,0023 & 0,157426 & 0,007 & 0,022394 & 0,0003 & 0,255196 & 257,47 & 108,32 & 148,45 & 6,14 & 142,77 & 1,60 & 96 \\
\hline $86-20$ & 93,737332 & $1.793,900$ & $1.607,434$ & 1,116002 & 0,054523 & 0,0026 & 0,163866 & 0,0075 & 0,022081 & 0,0003 & 0,273855 & 394,50 & 107,40 & 154,08 & 6,57 & 140,79 & 1,76 & 90 \\
\hline
\end{tabular}




\begin{tabular}{|c|c|c|c|c|c|c|c|c|c|c|c|c|c|c|c|c|c|c|c|c|c|}
\hline $\begin{array}{l}\text { Spot } \\
\text { Name }\end{array}$ & $\begin{array}{c}\text { Meas } \\
{ }^{204} \mathrm{~Pb} /{ }^{206} \mathbf{P b}\end{array}$ & $\begin{array}{l}\% \\
\text { err }\end{array}$ & $\begin{array}{c}\text { Meas } \\
{ }^{207} \mathrm{~Pb} /{ }^{206} \mathrm{~Pb}\end{array}$ & $\begin{array}{l}\% \\
\text { err }\end{array}$ & $\begin{array}{c}\text { Meas } \\
{ }^{208} \mathrm{~Pb} /{ }^{206} \mathrm{~Pb}\end{array}$ & $\begin{array}{l}\% \\
\text { err }\end{array}$ & $\begin{array}{c}\text { ppm } \\
\text { Th }\end{array}$ & $\underset{\mathbf{U}}{\mathbf{p p m}}$ & ${ }^{232} \mathbf{T h} /{ }^{2}$ & $\begin{array}{c}\text { Corr } \\
{ }^{206} \mathbf{P b} \mathbf{b}^{238} \mathrm{U}\end{array}$ & $\begin{array}{l}\% \\
\text { err }\end{array}$ & $\begin{array}{c}\text { ppm } \\
\text { Rad }{ }^{206} \mathrm{~Pb}\end{array}$ & $\begin{array}{c}{ }^{207} \text { corr } \\
{ }^{206} \mathrm{~Pb} /{ }^{238} \mathrm{U} \\
\text { Age }\end{array}$ & $\begin{array}{l}1 \sigma \\
\text { err }\end{array}$ & $\begin{array}{c}{ }^{204} \mathrm{Corr} \\
{ }^{207} \mathrm{~Pb} /{ }^{206} \mathrm{~Pb}\end{array}$ & $\begin{array}{l}\% \\
\text { err }\end{array}$ & $\begin{array}{c}{ }^{204} \mathrm{Corr} \\
{ }^{207} \mathrm{~Pb} /{ }^{235} \mathrm{U}\end{array}$ & $\begin{array}{l}\% \\
\text { err }\end{array}$ & $\begin{array}{l}{ }^{204} \mathrm{Corr} \\
{ }^{206} \mathrm{~Pb} /{ }^{238} \mathrm{U}\end{array}$ & $\begin{array}{l}\% \\
\text { err }\end{array}$ & $\begin{array}{l}\text { err } \\
\text { corr. }\end{array}$ \\
\hline \multicolumn{22}{|c|}{ Q-DIO-Quartz Diorite } \\
\hline Q-DIO-1.1 & $-0,000035$ & 107,54 & 0,048 & 3,64 & 0,173 & 4,64 & 73,46 & 145,3 & 0,52 & 0,027 & 1,47 & 3,4 & 174,79 & 2,57 & 0,049 & 3,78 & 0,19 & 4,05 & 0,0275 & 1,47 & 0,363 \\
\hline Q-DIO-2.1 & $-0,000045$ & 0,84 & 0,049 & 2,26 & 0,265 & 2,39 & 245,02 & 302,1 & 0,84 & 0,028 & 1,25 & 7,4 & 180,12 & 2,25 & 0,050 & 2,24 & 0,20 & 2,57 & 0,0283 & 1,25 & 0,489 \\
\hline Q-DIO-3.1 & 0,000145 & 24,81 & 0,051 & 2,08 & 0,344 & 1,97 & 342,94 & 320,6 & 1,11 & 0,029 & 1,24 & 8,0 & 184,55 & 2,27 & 0,048 & 2,51 & 0,19 & 2,80 & 0,0290 & 1,24 & 0,442 \\
\hline Q-DIO-4.1 & 0,000229 & 37,65 & 0,053 & 3,04 & 0,174 & 4,09 & 84,36 & 154,0 & 0,57 & 0,028 & 1,40 & 3,8 & 179,83 & 2,52 & 0,050 & 4,23 & 0,20 & 4,46 & 0,0283 & 1,41 & 0,316 \\
\hline Q-DIO-5.1 & 0,000018 & 919,16 & 0,049 & 2,61 & 0,274 & 3,17 & 226,59 & 246,1 & 0,95 & 0,029 & 1,30 & 6,0 & 181,65 & 2,37 & 0,049 & 5,61 & 0,19 & 5,77 & 0,0285 & 1,34 & 0,232 \\
\hline Q-DIO-6.1 & 0,000015 & 827,80 & 0,049 & 3,01 & 0,175 & 3,24 & 125,89 & 231,7 & 0,56 & 0,028 & 1,29 & 5,7 & 181,13 & 2,35 & 0,049 & 4,83 & 0,19 & 5,01 & 0,0285 & 1,32 & 0,263 \\
\hline Q-DIO-7.1 & 0,000120 & 38,91 & 0,051 & 2,45 & 0,183 & 3,14 & 136,57 & 244,3 & 0,58 & 0,028 & 1,29 & 5,9 & 178,40 & 2,30 & 0,050 & 2,94 & 0,19 & 3,21 & 0,0281 & 1,29 & 0,402 \\
\hline Q-DIO-8.1 & 0,000134 & 37,80 & 0,050 & 2,39 & 0,164 & 3,18 & 118,90 & 247,4 & 0,50 & 0,029 & 1,28 & 6,1 & 183,33 & 2,34 & 0,048 & 2,99 & 0,19 & 3,25 & 0,0288 & 1,28 & 0,394 \\
\hline Q-DIO-9.1 & 0,000016 & 101,57 & 0,051 & 2,41 & 0,207 & 3,58 & 148,72 & 238,6 & 0,64 & 0,028 & 1,28 & 5,8 & 178,96 & 2,29 & 0,051 & 2,47 & 0,20 & 2,78 & 0,0282 & 1,28 & 0,462 \\
\hline Q-DIO-10.1 & 0,000049 & 78,71 & 0,050 & 1,88 & 0,267 & 1,98 & 327,52 & 401,8 & 0,84 & 0,028 & 1,21 & 9,8 & 180,27 & 2,17 & 0,049 & 2,24 & 0,19 & 2,54 & 0,0284 & 1,21 & 0,475 \\
\hline Q-DIO-11.1 & 0,000000 & 0,00 & 0,048 & 3,51 & 0,184 & 4,66 & 85,61 & 139,3 & 0,63 & 0,027 & 1,46 & 3,2 & 170,62 & 2,50 & 0,048 & 3,51 & 0,18 & 3,80 & 0,0268 & 1,46 & 0,385 \\
\hline Q-DIO-12.1 & 0,000000 & 0,00 & 0,048 & 3,76 & 0,203 & 3,66 & 122,26 & 197,2 & 0,64 & 0,026 & 1,38 & 4,4 & 167,18 & 2,31 & 0,048 & 3,76 & 0,17 & 4,01 & 0,0262 & 1,38 & 0,344 \\
\hline Q-DIO-13.1 & 0,000152 & 73,38 & 0,050 & 2,87 & 0,192 & 3,55 & 100,40 & 167,7 & 0,62 & 0,028 & 1,42 & 4,0 & 178,31 & 2,53 & 0,048 & 4,60 & 0,19 & 4,82 & 0,0280 & 1,43 & 0,298 \\
\hline Q-DIO-14.1 & 0,000138 & 14,33 & 0,051 & 2,21 & 0,264 & 2,37 & 232,77 & 286,9 & 0,84 & 0,028 & 1,25 & 6,8 & 175,06 & 2,19 & 0,049 & 2,45 & 0,18 & 2,76 & 0,0275 & 1,25 & 0,455 \\
\hline Q-DIO-15.1 & 0,002241 & 37,18 & 0,083 & 11,96 & 0,297 & 8,56 & 156,72 & 241,6 & 0,67 & 0,029 & 1,28 & 6,1 & 179,67 & 3,38 & 0,050 & 34,17 & 0,19 & 34,30 & 0,0283 & 2,08 & 0,061 \\
\hline Q-DIO-12.2 & 0,000123 & 64,86 & 0,050 & 2,97 & 0,197 & 3,66 & 108,51 & 183,0 & 06 & 0,027 & 1,37 & 4,2 & 171,72 & 2,35 & 0,048 & 3,98 & 0,18 & 4,21 & 0,0269 & 1,38 & 0,326 \\
\hline Q-DIO-16.1 & $-0,000010$ & 83,68 & 0,048 & 2,29 & 0,291 & 2,27 & 248,48 & 283,8 & 0,9 & 0,027 & 1,25 & 6,6 & 171,30 & 2,14 & 0,049 & 2,30 & 0,18 & 2,62 & 0,0269 & 1,25 & 0,480 \\
\hline Q-DIO-17.1 & 0,000035 & 50,00 & 0,075 & 1,59 & 0,151 & 1,74 & 174,02 & 350,2 & 0,51 & 174 & 1,14 & 52,3 & $1.031,11$ & 11,40 & 0,075 & 1,64 & 1,79 & 1,99 & 0,1736 & 1,14 & 0,571 \\
\hline Q-DIO-18.1 & 0,000036 & 64,80 & 0,049 & 1,57 & 0,316 & 1,53 & 586,74 & 599,0 & 1,01 & 0,029 & 1,17 & 14,7 & 181,90 & 2,11 & 0,049 & 1,75 & 0,19 & 2,10 & 0,0286 & 1,17 & 0,556 \\
\hline Q-DIO-19.1 & 0,000090 & 147,01 & 0,051 & 2,31 & 6 & 2,87 & 160,82 & 258,6 & 0,64 & 28 & 1,27 & 62 & 176,98 & 2,24 & 0,050 & 4,62 &, 19 & 4,80 & & 1,29 & 0,269 \\
\hline Q-DIO-20.1 & 0,000134 & 74,26 & 0,051 & 2,03 & 0,240 & 2,29 & 254,33 & 337,0 & 0,78 & 0,028 & 1,23 & 8,1 & 178,31 & 2,18 & 0,049 & 3,71 & 0,19 & 3,91 & 0,0280 & 1,24 & 0,317 \\
\hline \multicolumn{22}{|c|}{ ZAD-DIO-Quartz Monzodiorite } \\
\hline ZAD-DIO-1.1 & 0,000299 & 45,46 & 0,054 & 3,83 & 0,183 & 4,09 & 73,96018 & 134,46 & 0,57 & 0,028 & 1,42 & 3,2 & 175,97 & 2,52 & 0,0496 & 5,96 & 0,19 & 6,13 & 0,0277 & 1,44 & 0,235 \\
\hline ZAD-DIO-2.1 & 0,000006 & $1.046,12$ & 0,050 & 2,18 & 0,191 & 2,70 & 181,8734 & 298,17 & 0,6 & 0,028 & 1,25 & 7,2 & 177,60 & 2,21 & 0,0499 & 2,88 & 0,19 & 3,14 & 0,0279 & 1,25 & 0,399 \\
\hline ZAD-DIO-1.2 & 0,000272 & 45,31 & 0,054 & 2,65 & 0,209 & 3,26 & 119,5844 & 194,89 & 0,63 & 0,029 & 1,34 & 4,9 & 183,87 & 2,46 & 0,0498 & 4,78 & 0,20 & 4,98 & 0,0289 & 1,36 & 0,273 \\
\hline ZAD-DIO-3.1 & 0,000167 & 37,81 & 0,052 & 2,65 & 0,237 & 3,01 & 133,9456 & 193,35 & 0,72 & 0,027 & 1,33 & 4,6 & 174,01 & 2,31 & 0,0493 & 3,44 & 0,19 & 3,69 & 0,0274 & 1,33 & 0,361 \\
\hline ZAD-DIO-4.1 & 0,000187 & 37,81 & 0,051 & 2,81 & 0,168 & 3,74 & 87,86189 & 181,34 & 0,50 & 0,028 & 1,35 & 4,3 & 174,55 & 2,35 & 0,0486 & 3,75 & 0,18 & 3,99 & 0,0274 & 1,35 & 0,339 \\
\hline ZAD-DIO-5.1 & 0,000004 & $2.830,50$ & 0,050 & 2,24 & 0,191 & 2,77 & 202,6828 & 329,35 & 0 & 0027 & 1,25 & 7 & 169,01 & 2,11 & 0,0499 & 3,94 & 0,18 & 4,14 & 0,0266 & 1,27 & 0,306 \\
\hline ZAD-DIO-6.1 & $-0,000045$ & 78,21 & 0,049 & 2,44 & 0,250 & 2,69 & 191,4484 & 247,18 & 0,80 & 0,028 & 1,29 & 5,9 & 175,70 & 2,26 & 0,0498 & 2,63 & 0,19 & 2,93 & 0,0276 & 1,29 & 0,440 \\
\hline ZAD-DIO-7.1 & 0,000033 & 302,00 & 0,051 & 2,13 & 0,221 & 2,46 & 215,9371 & 322,14 & 0,69 & 0,028 & 1,28 & 7,7 & 176,80 & 2,26 & 0,0501 & 3,63 & 0,19 & 3,85 & 0,0278 & 1,29 & 0,336 \\
\hline ZAD-DIO-8.1 & 0,000138 & 151,25 & 0,050 & 3,38 & 0,166 & 4,39 & 63,03425 & 130,3 & 0,50 & 0,028 & 1,52 & 3,1 & 177,30 & 2,70 & 0,0484 & 7,32 & 0,19 & 7,49 & 0,0278 & 1,57 & 0,210 \\
\hline ZAD-DIO-9.1 & 0,000110 & 62,42 & 005 & 2,38 & 0214 & 2,80 & 175,7438 & 262,13 & 06 & 0 0 & 1,2 & 65 & 182,95 & 2,3 & 0,0493 & 3,23 & 0,20 & 3,48 & 0,0288 & 1,28 & 0,369 \\
\hline ZAD-DIO-10.1 & 0,000000 & 0,00 & 0,049 & 3,13 & 0,232 & 3,55 & 112,6739 & 154,16 & 0,76 & 0,028 & 1,41 & 3,8 & 180,73 & 2,54 & 0,0494 & 3,13 & 0,19 & 3,43 & 0,0284 & 1,41 & 0,410 \\
\hline ZAD-DIO-11.1 & $-0,000007$ & 1,24 & 0,050 & 3,35 & 0,213 & 4,14 & 95,30003 & 143,54 & 0,69 & 0,028 & 1,43 & 3,5 & 178,16 & 2,55 & 0,0497 & 3,34 & 0,19 & 3,63 & 0,0280 & 1,43 & 0,393 \\
\hline ZAD-DIO-12.1 & $-0,000026$ & 70,54 & 0,050 & 2,06 & 0,283 & 2,11 & 307,5458 & 348,46 & 0,91 & 0,027 & 2,03 & 8,1 & 172,08 & 3,46 & 0,0501 & 2,12 & 0,19 & 2,93 & 0,0271 & 2,03 & 0,692 \\
\hline ZAD-DIO-12.2 & 0,000080 & 85,69 & 0,050 & 1,99 & 0,233 & 2,22 & 315,9783 & 429,81 & 07 & 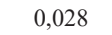 & 1,21 & 10,2 & 176,3 & 2,1 & 0,0485 & 2,94 & 0,19 & 3,18 & 0,0277 & 1,22 & 0,383 \\
\hline ZAD-DIO-13.1 & 0,000221 & 34,77 & 005 & 2,12 & 020 & 2,62 & 182,3148 & 297,05 & 0,6 & & 1,25 & 7, & 176,27 & 2,19 & & 3,37 & 0,19 & 3,60 & 0,0277 & 1,26 & 0,348 \\
\hline ZAD-DIO-14.1 & $-0,000029$ & 0,77 & 0,050 & 2,53 & 0,234 & 2,82 & 157,0875 & 216,73 & 0,75 & 0,028 & 1,30 & 5,2 & 176,25 & 2,28 & 0,0507 & 2,51 & 0,19 & 2,82 & 0,0278 & 1,30 & 0,459 \\
\hline ZAD-DIO-15.1 & $-0,000133$ & 1,28 & 0,050 & 2,36 & 0,304 & 2,34 & 227,9399 & 250,81 & 0,94 & 0,027 & 1,27 & 5,8 & 172,46 & 2,19 & 0,0519 & 2,32 & 0,19 & 2,65 & 0,0272 & 1,27 & 0,481 \\
\hline ZAD-DIO-16.1 & $-0,000011$ & 107,53 & 0,049 & 2,44 & 0,168 & 3,21 & 126,7434 & 246,27 & 0,53 & 0,028 & 1,28 & 5 , & 175,58 & 2,24 & 0,0493 & 2,46 & 0,19 & 2,77 & 0,0276 & 1,28 & 0,461 \\
\hline ZAD-DIO-17.1 & 0,000074 & 72,78 & & 1,99 & & 2,28 & 280,434 & 361 , & 0,80 & & 1,48 & 8,6 & & 2,59 & & 2,59 & 0,19 & 2,98 & 0,0277 & 1,48 & 0,497 \\
\hline ZAD-DIO-11.2 & $-0,000065$ & 68,85 & 0,049 & 2,69 & 0,208 & 3,16 & 151,115 & 228,5 & 0,68 & 0,028 & 1,51 & 5,4 & 176,54 & 2,66 & 0,0498 & 2,96 & 0,19 & 3,33 & 0,0278 & 1,52 & 0,456 \\
\hline ZAD-DIO-18.1 & $-0,000038$ & 61,24 & 0,049 & 2,08 & 0,200 & 2,68 & 197,642 & 313,81 & 0,65 & 0,027 & 1,27 & 7,4 & 174,17 & 2,20 & 0,0495 & 2,18 & 0,19 & 2,52 & 0,0274 & 1,27 & 0,503 \\
\hline
\end{tabular}




\begin{tabular}{|c|c|c|c|c|c|c|c|c|c|c|c|c|c|c|c|c|c|c|c|c|c|}
\hline $\begin{array}{l}\text { Spot } \\
\text { Name }\end{array}$ & $\begin{array}{c}\text { Meas } \\
{ }^{204} \mathrm{~Pb} /{ }^{206} \mathrm{~Pb}\end{array}$ & $\begin{array}{l}\% \\
\text { err }\end{array}$ & $\begin{array}{c}\text { Meas } \\
{ }^{207} \mathrm{~Pb} /{ }^{206} \mathrm{~Pb}\end{array}$ & $\begin{array}{l}\% \\
\text { err }\end{array}$ & $\begin{array}{c}\text { Meas } \\
{ }^{208} \mathrm{~Pb} /{ }^{206} \mathrm{~Pb}\end{array}$ & $\begin{array}{l}\% \\
\text { err }\end{array}$ & $\begin{array}{c}\text { ppm } \\
\text { Th }\end{array}$ & $\underset{\mathbf{U}}{\mathbf{p p m}}$ & $\mathbf{T h} /{ }^{2}$ & $\begin{array}{c}\text { Corr } \\
{ }^{206} \mathrm{~Pb} \mathbf{P b}^{238} \mathrm{U}\end{array}$ & $\begin{array}{c}\% \\
\text { err }\end{array}$ & $\begin{array}{c}\text { ppm } \\
\operatorname{Rad}^{206} \mathrm{~Pb}\end{array}$ & $\begin{array}{c}{ }^{207} \mathrm{corr} \\
{ }^{206} \mathrm{~Pb} /{ }^{238} \mathrm{U} \\
\mathrm{Age}\end{array}$ & $\begin{array}{l}1 \sigma \\
\text { err }\end{array}$ & $\begin{array}{c}{ }^{204} \mathrm{Corr} \\
{ }^{207} \mathrm{~Pb} /{ }^{206} \mathrm{~Pb}\end{array}$ & $\begin{array}{l}\% \\
\text { err }\end{array}$ & $\begin{array}{c}{ }^{204} \mathrm{Corr} \\
{ }^{207} \mathrm{~Pb} /{ }^{/ 355} \mathrm{U}\end{array}$ & $\begin{array}{l}\% \\
\text { err }\end{array}$ & $\begin{array}{c}{ }^{204} \mathrm{Corr} \\
{ }^{206} \mathrm{~Pb} /{ }^{238} \mathrm{U}\end{array}$ & $\begin{array}{l}\% \\
\text { err }\end{array}$ & $\begin{array}{l}\text { err } \\
\text { corr. }\end{array}$ \\
\hline \multicolumn{22}{|c|}{ M-DIO-Microdiorite } \\
\hline M-DIO-1.1 & $6,283 \mathrm{E}-05$ & 112,3 & . & 1,603 & 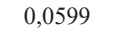 & 3,74 & 40,35 & 194,53 & 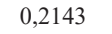 & 5 & 1,24 & 12,96 & 480,88 & 5,78 & 0 & 2,47 & 8 & 2,77 & 0,0774 & 1,25 & 0,4506 \\
\hline M-DIO-2.1 & 163E-05 & 56,8 & 0,0546 & 1,610 & 0,0800 & 2,37 & 134,67 & 527,22 & 0,2639 & 0,0524 & 1,18 & 23,71 & 328,48 & 3,78 & 0,05 & 2,10 & 385 & 2,41 & 0,0523 & 1,18 & 0,4887 \\
\hline M-DIO-3.1 & $1,073 \mathrm{E}-04$ & 109,2 & 540 & 2,114 & 0,2454 & 2,42 & 140,79 & 182,38 & 0,7976 & 0,0510 & 1,28 & 99 & 319,90 & 4,06 & 0, & 3,96 & 8 & 4,17 & 0 , & 1,30 & 0,3125 \\
\hline M-DIO-4.1 & $-2,129 \mathrm{E}-05$ & ,3 & 775 & 0,620 & 996 & 1,41 & ,47 & 184,62 & 0 , & 0 , & 1,32 & 49,09 & $1.738,98$ & 20,10 & 11 & 0,62 & 4 & 46 & 0 , & 1,32 & 0,9053 \\
\hline M-DIO-5.1 & $2,502 \mathrm{E}-05$ & 28,4 & 76 & 0,500 & 0,3433 & 0,57 & 475,10 & 406,94 & 1,2063 & 0,3104 & 1,13 & 108,51 & $1.741,86$ & 17,30 & 11 & 0,51 & 90 & 1,24 & 0,3102 & 1,13 & 0,9113 \\
\hline M-DIO-6.1 & 8,937E-06 & 196,3 & 0,0568 & 1,231 & 0,0293 & 4,05 & 29,86 & 329,49 & 0,0937 & 0,0771 & 1,20 & 21,82 & 478,70 & 5,53 & 0,06 & 1,31 & 0,602 & 1,78 & 0,0771 & 1,20 & 0,6738 \\
\hline M-DIO-7.1 & $2,408 \mathrm{E}-05$ & 44,5 & 0,1084 & 0,654 & 0,3963 & 0,82 & 208,67 & 153,68 & 1,4030 & 0,3225 & 1,21 & 42,58 & $1.801,45$ & 19,07 & 0,11 & 0,67 & 4,804 & 1,39 & 0,3224 & 1,21 & 0,8750 \\
\hline M-DIO-1.2 & $4,290 \mathrm{E}-05$ & 152,3 & 572 & 1,994 & 0,1653 & 2, & 2,39 & 158,43 & 0,5373 & 0,0771 & 1,27 & 10,50 & 478,59 & 5,89 & 0,06 & 2,63 & 0,601 & 2,93 & 0,0771 & 1,28 & 0,4365 \\
\hline M-DIO-8.1 & $6,445 \mathrm{E}-05$ & 45,0 & 0,0760 & 0,911 & 0,0333 & 2,93 & 43,84 & 409,58 & 0,1106 & 0,1797 & 1,14 & 63,24 & $1.064,21$ & 11,20 & 0,08 & 1,09 & 58 & 1,58 & 0,1795 & 1,14 & 0,7236 \\
\hline M-DIO-8.2 & 1,163E-05 & 38,9 & 0,0860 & 0,603 & 0,0520 & 8,77 & 57,00 & 381,25 & 0,1545 & 0,2033 & 1,27 & 66,60 & $1.193,02$ & 13,84 & 0,09 & 0,61 & 2,406 & 1,41 & 0,2033 & 1,27 & 0,9015 \\
\hline M-DIO-9.1 & $8,047 \mathrm{E}-05$ & 33,3 & 0,0806 & 0,662 & 0,3168 & 0,91 & 339,93 & 328,83 & 1,0681 & 0,2046 & 1,15 & 57,79 & $1.198,13$ & 12,58 & 0,08 & 0,85 & 2,239 & 1,43 & 0,2043 & 1,15 & 0,8043 \\
\hline M-DIO-9.2 & $3,788 \mathrm{E}-05$ & 46,9 & 0,0795 & 0,810 & 0,1304 & 1,68 & 96,90 & 215,12 & 0,4654 & 0,2017 & 1,18 & 37,28 & $1.183,91$ & 12,77 & 0,08 & 0,88 & 2,196 & 1,47 & 0,2016 & 1,18 & 0,8016 \\
\hline M-DIO-10.1 & $1,360 \mathrm{E}-03$ & 30,2 & 0,0690 & 5,199 & 0,3135 & 2,82 & 195,27 & 257,76 & 0,7828 & 0,0290 & 1,34 & 6,42 & 179,66 & 2,76 & 0,05 & 15,8 & 0,191 & 15,89 & 0,0283 & 1,56 & 0,0983 \\
\hline M-DIO-11.1 & $9,870 \mathrm{E}-05$ & 61,7 & 0,0560 & 0,971 & 0,0674 & 2,11 & 124,32 & 619,86 & 0,2072 & 0,0635 & 1,15 & 33,82 & 396,21 & 4,43 & 0,05 & 1,95 & 0,477 & 2,26 & 0,0634 & 1,15 & 0,5089 \\
\hline M-DIO-12.1 & $6,680 \mathrm{E}-05$ & 40,8 & 0,1065 & 1,170 & 0,4248 & 1,36 & 219,51 & 150,34 & 1,5087 & 0,3042 & 1,20 & 39,29 & $1.710,23$ & 18,11 & 0,11 & 1,24 & 4,425 & 1,73 & 0,3038 & 1,21 & 0,6971 \\
\hline M-DIO-13.1 & $8,609 \mathrm{E}-05$ & 38,7 & 0,0809 & 0,590 & 0,2760 & 0,77 & 349,20 & 398,96 & 0,9044 & 0,1949 & 1,13 & 66,81 & $1.146,28$ & 11,92 & 0,08 & 0,87 & 2,139 & 1,43 & 0,1946 & 1,13 & 0,7935 \\
\hline M-DIO-14.1 & $666 \mathrm{E}-04$ & 57,0 & 0,1073 & 1,090 & 0,3996 & 1,65 & 102,26 & 75,91 & 1,3920 & 0,2778 & 1,85 & 18,12 & $1.575,92$ & 25,97 & 0,11 & 1,69 & 4,010 & 2,52 & 0,2769 & 1,86 & 0,7388 \\
\hline M-DIO-3.2 & $1,256 \mathrm{E}-04$ & 34,2 & 0,0522 & 1,787 & 0,2967 & 1,84 & 244,99 & 260,37 & 0,9722 & 0,0509 & 1,22 & 11,38 & 319,08 & 3,82 & 0,05 & 2,30 & 0,353 & 2,60 & 0,0507 & 1,23 & 0,4706 \\
\hline
\end{tabular}

